\title{
Permafrost soils and carbon cycling
}

\author{
C. L. Ping ${ }^{1}$, J. D. Jastrow ${ }^{2}$, M. T. Jorgenson ${ }^{3}$, G. J. Michaelson ${ }^{1}$, and Y. L. Shur ${ }^{4}$ \\ ${ }^{1}$ Agricultural and Forestry Experiment Station, Palmer Research Center, University of Alaska Fairbanks, \\ 1509 South Georgeson Road, Palmer, AK 99645, USA \\ ${ }^{2}$ Biosciences Division, Argonne National Laboratory, Argonne, IL 60439, USA \\ ${ }^{3}$ Alaska Ecoscience, Fairbanks, AK 99775, USA \\ ${ }^{4}$ Department of Civil and Environmental Engineering, University of Alaska Fairbanks, Fairbanks, \\ AK 99775, USA \\ Correspondence to: C. L. Ping (cping@ alaska.edu)
}

Received: 4 October 2014 - Published in SOIL Discuss.: 30 October 2014

Revised: - - Accepted: 24 December 2014 - Published: 5 February 2015

\begin{abstract}
Knowledge of soils in the permafrost region has advanced immensely in recent decades, despite the remoteness and inaccessibility of most of the region and the sampling limitations posed by the severe environment. These efforts significantly increased estimates of the amount of organic carbon stored in permafrost-region soils and improved understanding of how pedogenic processes unique to permafrost environments built enormous organic carbon stocks during the Quaternary. This knowledge has also called attention to the importance of permafrost-affected soils to the global carbon cycle and the potential vulnerability of the region's soil organic carbon (SOC) stocks to changing climatic conditions. In this review, we briefly introduce the permafrost characteristics, ice structures, and cryopedogenic processes that shape the development of permafrost-affected soils, and discuss their effects on soil structures and on organic matter distributions within the soil profile. We then examine the quantity of organic carbon stored in permafrost-region soils, as well as the characteristics, intrinsic decomposability, and potential vulnerability of this organic carbon to permafrost thaw under a warming climate. Overall, frozen conditions and cryopedogenic processes, such as cryoturbation, have slowed decomposition and enhanced the sequestration of organic carbon in permafrost-affected soils over millennial timescales. Due to the low temperatures, the organic matter in permafrost soils is often less humified than in more temperate soils, making some portion of this stored organic carbon relatively vulnerable to mineralization upon thawing of permafrost.
\end{abstract}

\section{Introduction}

Permafrost soils are unique among the world's soils because their form and function are greatly affected by cold temperatures and by the presence of perennially frozen ground beneath their seasonally thawed layer (Karavaeva, 1969; Tedrow, 1974; Everett et al., 1981; Makeev, 1981; Ping et al., 1998; Tarnocai et al., 2009; Jones et al., 2010). Low temperatures and seasonal freezing and thawing lead to strong heaving forces, differential thaw settlement, development of segregated and massive ice, and a bewildering variety of patterned ground features. Because the underlying permafrost impedes subsurface drainage, soils are often wet as well as cold, which greatly affects oxidation/reduction, decomposition, and other biogeochemical processes. Low decomposition rates, cryoturbation resulting from freeze-thaw processes, and depositional environments dating back to the Pleistocene have led to the accumulation of large stores of organic carbon in the active layer and underlying permafrost. Due to these unique characteristics, permafrost-affected soils (commonly termed permafrost soils) are differentiated at the highest levels in most national and international soil classification systems.

The enormous organic carbon accumulations in these soils make them important to the global climate system because of their potential to thaw, decompose organic matter accu- 
mulated over long periods, and release greenhouse gases into the atmosphere. Soils in the northern circumpolar permafrost region are estimated to store $\sim 1000 \mathrm{Pg} \mathrm{C}$ (carbon) in the surface $0-3 \mathrm{~m}$ and permafrost-affected soils account for $70 \%$ of this carbon (Tarnocai et al., 2009; Hugelius et al., 2014). Because of the large carbon stocks, there are increasing concerns about the potential release of significant amounts of this carbon as greenhouse gases, especially for methane with its greater warming potential compared to carbon dioxide (McGuire et al., 2009; Schuur et al., 2011). The release of carbon may be exacerbated by a strong positive feedback loop where rising soil temperatures and accelerated permafrost degradation lead to increased decomposition of stored organic matter (Oechel et al., 1993; Koven et al., 2011; Harden et al., 2012). However, once permafrost thaws there are radical changes in hydrology, soil conditions, and vegetation communities that create substantial uncertainty as to how quickly and in what direction the thawing of permafrost soils will affect soil carbon balance, greenhouse gas emissions, and climate change (McGuire et al., 2009; Olefeldt et al., 2013; Jorgenson et al., 2013; Walter Anthony et al., 2014).

In this review, we highlight and discuss important factors affecting the patterns, processes, and carbon stocks of permafrost soils, and summarize recent research developments. In Sect. 2 on permafrost characteristics and transformations, we discuss the formation and distribution of permafrost, effects of cryogenesis on cryostructure patterns, the importance of periglacial freeze-thaw processes on patterned ground, and the consequences of thermokarst landforms resulting from degrading permafrost. In Sect. 3 on cryopedogenesis, we review how biochemical processes are affected by low temperatures, how soil structures differ in the active layer compared to the upper permafrost, and the classification of permafrost soils. In Sects. 4-6 on organic carbon in permafrost soils, we examine permafrost-related factors affecting soil organic carbon (SOC) accumulation, the quantity of organic carbon held in permafrost soils, and its quality and decomposability. Finally, in Sect. 7, we review recent research on the emerging role of permafrost soils in climatic change.

\section{Permafrost characteristics and transformations}

\subsection{Permafrost formation and distribution}

Permafrost is defined as ground (soil or rock, and included ice) that remains at or below $0{ }^{\circ} \mathrm{C}$ for at least two consecutive years (Sumgin, 1927; Washburn, 1973). Permafrost underlies approximately $22.79 \times 10^{6} \mathrm{~km}^{2}$, nearly $24 \%$ of the landmass of the Northern Hemisphere or $\sim 15 \%$ of the global landmass (Zhang et al., 2008). Permafrost terrain occurs mostly in the lowlands, hills and mountains of the circumpolar region, the boreal regions, and high alpine and plateau regions in the Northern Hemisphere (Zhang et al., 2008), in
Antarctica, and in limited areas of high alpine regions in the Southern Hemisphere (Bockheim, 1995; Brown et al., 2001). The non-ice-covered land areas of the northern circumpolar region encompass $17.8 \times 10^{6} \mathrm{~km}^{2}$, and permafrost-affected soils account for $57 \%$ of this land area (Hugelius et al., 2014).

There are two general types of permafrost. The most common type is the old permafrost, a remnant of paleoclimate, and the other type formed more recently, under contemporary conditions. The old permafrost is widespread throughout the lowlands and hills of the northern circumpolar region (Gubin, 1993; Péwé, 1975; Kanevskiy et al., 2011; Winterfeld et al., 2011). Much of this relic permafrost is polygenetic in that syngenetic permafrost developed on epigenetic permafrost. Examples include the Yedoma formations in northeastern Russia, Arctic and boreal Alaska (Reyes et al., 2010; Schirrmeister et al., 2011a, b; Kanevskiy et al., 2011, 2014), and the Yukon regions in Canada (Froese et al., 2008). Yedoma is also called "Ice Complex" because of the huge ice wedges formed in thick deposits of syngenetic origin (i.e., concurrent upward growth of deposits and the permafrost surface). Most epigenetic permafrost (which develops on existing deposits) formed in uplands, such as the glaciated uplands of North America. The second, more modern kind of permafrost was formed during the Holocene as a result of deglaciation followed by vegetation succession under cold climatic conditions, and is mostly located in the sub-Arctic and boreal regions (Zoltai and Tarnocai, 1975). This more recently formed type has been termed "ecosystem-driven permafrost" (Shur and Jorgenson, 2007). In general, most permafrost in the Arctic is of late-Pleistocene age (Brown, 1965; Gubin, 1993; Gubin and Lupachev, 2008; Kanevskiy et al., 2011; Schirrmeister et al., 2011a). In the Dry Valley region of Antarctica, the permafrost is even older, as it formed during the pre-late Quaternary (Bockheim, 1995; Campbell et al., 1998). However, the upper permafrost of the old formations is subject to change under contemporary climate fluctuations.

\subsection{Cryogenesis and cryostructure}

Permafrost affects soil formation through physical and biological processes. Permafrost exerts a controlling role on soil physical and morphological properties through cryogenesis, i.e., frost cracking and the formation of ice crystals and lens cryostructures that result in frost heaving and cryoturbation (Konishchev, 1982; Rieger, 1983; Mueller et al., 1999; Ping et al., 2008a). Cryostructures are defined as patterns formed by ice inclusions in the frozen soil (Kanevskiy et al., 2011). These inclusions form as ice crystals and lenses and as layers of segregated ice in the mineral soil matrix due to freezing conditions within the soil (Shur and Jorgenson, 1998; Shur et al., 2005; French and Shur, 2010). There are seven major types of ice cryostructures in the active layer and the upper permafrost: structureless (pore), lenticular (micro-lenticular: $<0.5 \mathrm{~mm}$ thick; lenticular: $>0.5 \mathrm{~mm}$ thick), layered, retic- 
ulate, irregular reticulate (braided), crustal, and suspended (ataxitic) (Mackay, 1974; Murton and French, 1994; French and Shur, 2010). Some examples of these cryostructures are shown in Fig. 1. Upon desaturation after thawing, these cryostructures generally leave soil with platy, blocky, wedgeshaped, granular, or massive structures (Smith et al., 1991; Ping, 2013).

According to Gubin and Lupachev (2008) and French and Shur (2010), a permafrost soil profile commonly consists of three layers referred to as active, transient, and intermediate layers. But, considering the whole cryostratigraphy, the profile also should include a fourth layer - the "true permafrost", which often contains buried or paleo-genetic horizons (Höfle and Ping, 1996; Schirrmeister et al., 2002a, 2008, 2011a; Kanevskiy et al., 2014). The active layer is defined as the zone of the soil profile above the permafrost that is subject to annual freeze-thaw cycles (Burn, 1998). The active layer is the modern soil (mostly formed since the Holocene and a product of the contemporary climate) that undergoes seasonal thawing. The active layer typically consists of a surface organic horizon $(\mathrm{O})$ - with or without a humus-rich surface mineral horizon (A) - and a cambic horizon (Bw, Bg). But, the entire active layer can consist of just mineral or organic horizons (Ping et al., 1998, 2013). The transient layer (the uppermost part of the permafrost) results from fluctuations of the permafrost table that have occurred on a decadal scale and has distinct layered, lenticular and reticulate cryostructures (Shur et al., 2005). The intermediate layer is caused by aggradation of permafrost due to soil climate changes resulting from the buildup of surface organic horizons on a decadal to century scale. The intermediate layer is characterized by ice-rich cryostructures that are referred to as "suspended" (or "ataxitic") because blocks of soil are suspended in an ice matrix (Fig. 1). Together the transient and intermediate layers comprise the uppermost section of permafrost (Shur, 1988), and below it is the "true" permafrost, which has remained frozen and not been subjected to freeze-thaw cycles on a century to millennial scale (French and Shur, 2010).

\subsection{Periglacial processes and patterned ground}

Toward the end of the growing season, solar radiation decreases, and the active layer starts to refreeze. In the continuous permafrost zone with cold permafrost, the active layer begins to refreeze from both the top down and the bottom up, while in the discontinuous zone with warmer permafrost, the active layer freezes only from the top down. The part of the active layer that has not yet frozen is isothermal and is called the "zero-curtain envelope" (Rieger, 1983; Davis, 2001). The zero curtain in the active layer lasts from the initiation of refreezing each year until the layer is completely frozen. In the Arctic, for example at Barrow, Alaska, the zero curtain only lasts for several weeks (Outcalt et al., 1990). In the discontinuous permafrost zone, for example in Fairbanks, Alaska, the zero curtain occurs for several months. But, in warm winters or those with a thick snow cover, part of the active layer can remain unfrozen, maintaining the zero curtain effect through the entire winter (Jorgenson et al., 2000). During the freeze-up process, lenticular, reticulate, and/or layered cryostructures form in both the upper and lower parts of the active layer, drawing soil water away from the middle part of the active layer and leaving it relatively dry. This leaves a desiccated layer with either coarse platy or massive soil structure (Shur and Ping, 1994). The exception is in poorly drained soils, where there is adequate water to sustain layered cryostructure development throughout the entire active layer.

Frost heave is caused by volumetric changes associated with the phase change of water to ice. Heaving due to ice segregation and ice-lens formation often results in deformation of the ground surface. With horizontal expansion limited, there is often enough stress to produce crooked or tilted lenticular and reticulate structures (Murton and French, 1994). Differential frost heave eventually deforms originally flat horizons into warped or wavy horizons. When freezing occurs in saturated coarse-grained soil, the cryostatic pressure pushes water out of the soil, producing intrusive-ice features such as icing blisters and frost blisters (Tsytovich, 1975; van Everdingen, 1978).

Soil deformation occurs during active-layer freezing. When fine-grained soil of the active layer freezes from above and below on two freezing fronts as a closed system, water migrates to both freezing fronts. This movement causes the upper and lower parts of the active layer to become saturated with ice and leads to formation of vertical cracks in the desiccated part of the active layer. In contrast, during freeze up in an open system, the flow of water through the active layer can create artesian pressure that forces water out of late freezing areas (e.g., near the base of hillslopes). Ice buildup in these areas produces cracked and broken surface soil horizons (Zhestkova, 1982). When ice-rich layers below the active layer thaw, the release and movement of water leads to a type of micro-scale diapirism, where water and saturated materials are forced through brittle layers or cracks while heavier mineral- and organic-rich soils fill the ensuing voids (Swanson et al., 1999).

Patterned ground derived from freeze-thaw processes greatly affects soil formation and the complexity of soils on the micro-scale. Common patterned ground types include ice-wedge polygons, sorted and nonsorted circles, stone nets, stripes, and gelifluction lobes (Washburn, 1973). Ice-wedge polygons form when contraction and expansion of the icesoil permafrost matrix create a large-scale net of cracks (5$50 \mathrm{~m}$ diameter polygon units) in winter. The thermal cracks fill with water during the warm season and refreeze immediately (Lachenbruch, 1966). This process repeats itself annually in new cracks in roughly the same areas to build wedges that control surface water distribution and deform developing soils (Kanevskiy et al., 2013; Ping et al., 1998). 


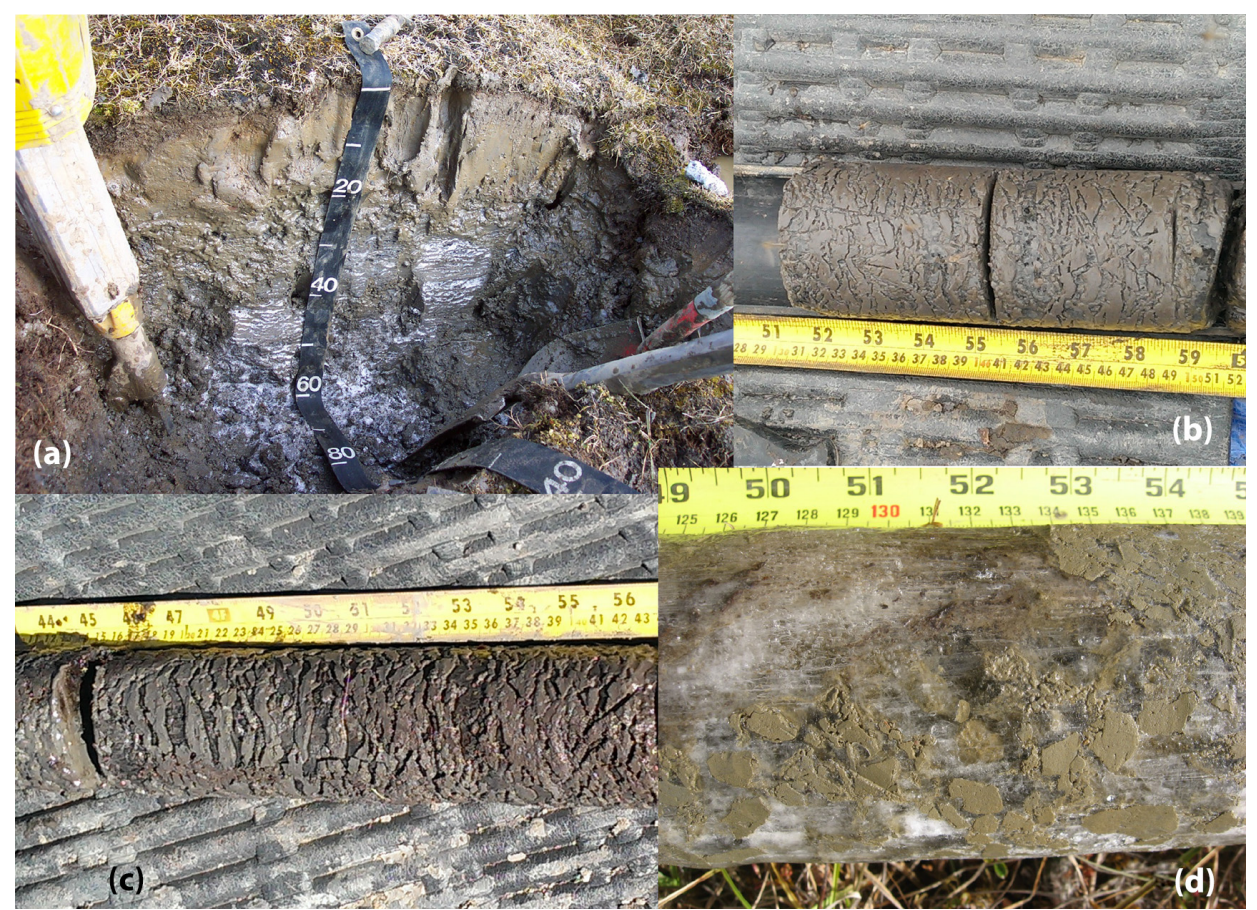

Figure 1. Examples of common cryostructures: (a) lenticular structures visible below $30-40 \mathrm{~cm}$ in a freshly exposed profile of an earth hummock, Mould Bay, Arctic Canada (reprinted by permission, ASA, CSSA, SSSA); (b) lenticular structures transition to a reticulate structure at $130-150 \mathrm{~cm}$ in a core extracted from the center of a low-centered ice-wedge polygon; (c) lenticular structure; and (d) suspended (ataxitic) structure.

Circle pattern formation generally is initiated by frost cracking of the active-layer ground followed by repeated freeze-thaw cycles, after which the thermo-hydrologic conditions around the cracks are modified by vegetation and ice aggradation (Shur et al., 2008; Walker et al., 2008). As a result of these modified thermo-hydrologic conditions, the surfaces across circles heave at differential rates, with greater heaving in the centers relative to the margins. For soils without rock fragments, materials within and outside the circles have the same general texture, and these are classified as "nonsorted" circles or more commonly "frost boils". For soils with rock fragments that tend to heave up, these fragments are eventually pushed to the outer edge of the circle by repeated cycles of frost action, forming segregated domains of soil and rock that are referred to as "sorted" circles (Washburn, 1973). In the initial stage, circle formation leaves the soil surface devoid of vegetation. Progressively, vegetation communities establish and an organic horizon starts to build. However, with continued annual differential heaving of the circle surface, the surface organic mat often becomes ruptured, forming discontinuous surface organic horizons. On slopes, gravitational forces can cause both nonsorted and sorted circles to deform downslope as they go through their annual freeze-thaw cycles, and these deformations develop into patterns known as stripes, or stone stripes when rock fragments are present (Marr, 1969; Geisler and Ping, 2013).
Oriented rocks are common in sorted circles. Orientation of rocks is caused by thermally induced frost heave, similar to a common phenomenon observed in soils wherever seasonal frost occurs. The mechanism driving rock orientation is that the longest rock axis tends to orient itself perpendicularly to the frost table, while the short axis lies parallel in order to minimize resistance (Washburn, 1973; Davis, 2001). Silt-capped rocks commonly occur in fragmental soils on exposed landscapes in the Arctic and alpine regions (Munn and Spackman, 1990). The freeze-thaw cycles contribute to the grinding of rock fragments into silt-sized particles, which are then transported by percolating water and accumulate on the upward facing surfaces of stones.

Patterned ground formation can cause large- and smallscale variation in soil types across the Arctic landscape. For example, across ice-wedge polygons, soils in the polygon troughs often have moderately thick peat underlain by massive ice; soils on the rims are better drained with welldecomposed organic matter forming A horizons (Fig. 2); while soils in the polygonal centers have thick peats over mineral sediment with different degrees of cryoturbation (Ping et al., 1998, 2011). For circle patterns, the small-scale net of cracks $(0.5-5 \mathrm{~m})$ in the active layer affects moisture availability, plant community distributions and differential active-layer dynamics (Walker et al., 2008), and creates different soil profile characteristics across the circles (Michaelson et al., 2008). 


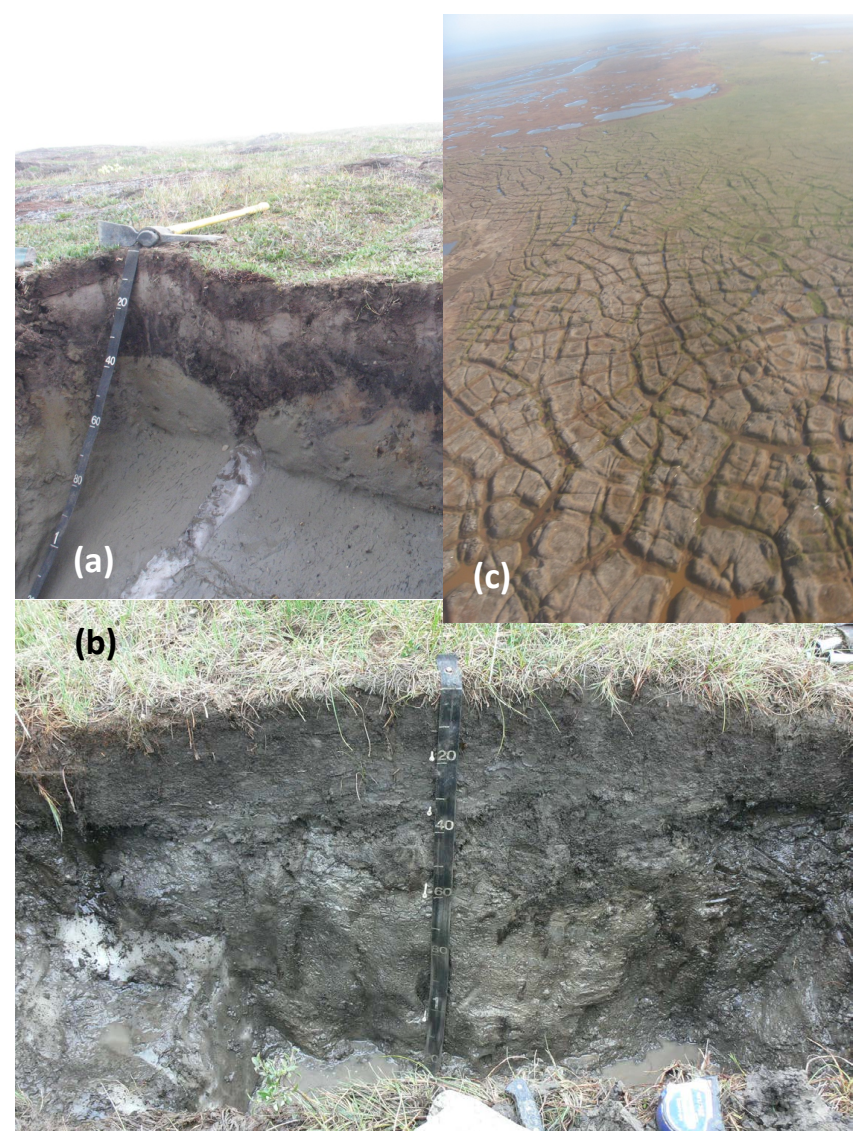

Figure 2. Soils formed in ice-wedge polygons: (a) active layer deformed by newly formed ice wedge $(7 \mathrm{~cm}$ wide); (b) cryoturbated polygon rim of a flat-centered ice-wedge polygon (ice wedge is $85 \mathrm{~cm}$ wide); and (c) an aerial view of the ice-wedge polygondominated landscape of the Arctic Coastal Plain, Alaska.

\subsection{Thermokarst}

Freezing of fine-grained soil attracts water to the freezing front from unfrozen soil below. As this water freezes within existing pore spaces, it can increase pore volumes by pushing soil solids apart, often forming lenses and layers of ice. Ice buildup can greatly increase the volume of pores present in soil compared to before freezing. When permafrost thaws and ice is lost from these pores, this causes the soil surface to settle or liquefy, and the amount of settlement is directly related to the amount and type of ice (Shur and Osterkamp, 2007). The irregular topography resulting from the melting of excess ground ice and subsequent ground collapse is called thermokarst. Czudek and Demek (1970) identified two types of thermokarst. The first type is permafrost "back-wearing", which commonly occurs in areas of dissected relief and develops gullies, thermocirques, parallel retreat of steep walls with ice veins, and eventually lowerlevel lowlands. The second type is referred to as "downwearing" because it is caused by permafrost thawing from above. This type is usually found in areas with flat undis- sected relief and typically produces flat-bottomed depressions with steep slopes - such as "alases", a Russian term used to describe this landform and thermokarst processes leading to its formation. The patterns and amount of settlement (or loss) of surficial material are related to complex interactions among slope position, soil texture, hydrology, and vegetation over time (Shur and Jorgenson, 2007). The highly variable terrain and an array of permafrost factors can lead to a wide variety of thermokarst landforms that include degrading ice-wedge troughs, thermokarst pits, thermokarst lakes, thermokarst bogs, thaw slumps, active-layer detachment slides, and thermal erosion gullies (Grosse et al., 2013; Kokelj and Jorgenson, 2013; Jorgenson et al., 2013; Jensen et al., 2014).

Thermokarst is widespread throughout the Arctic and boreal regions and has large implications for soil hydrology and carbon balance (Burn and Smith, 1990; Schuur et al., 2008; Veremeeva and Gubin, 2009; Grosse et al., 2011). Thermokarst lakes often develop taliks (unfrozen thaw bulbs) underneath the deep water, and resulting heattransfer dynamics can lead to degradation of adjacent permafrost, lake-bottom subsidence, and lateral lake expansion. Through these processes, organic matter that has long been sequestered in permafrost and reworked by shoreline erosion can decompose and release greenhouse gases (Walter et al., 2007; Grosse et al., 2013). But, thermokarst lakes and their expansion can also provide good conditions for enhanced primary productivity and carbon gain (Walter-Anthony et al., 2014). Thermokarst bogs in the boreal region also develop thick taliks, where organic matter in previously frozen soils becomes susceptible to decomposition. However, rapid sedge and Sphagnum colonization in the depressions can add new peat, and the net effect on carbon balance is uncertain (Sannel and Kuhry, 2011; Jorgenson et al., 2013). Degradation of ice wedges in the Arctic has increased, creating trough-like depressions that collect water and provide an anaerobic environment for new peat accumulation while the adjacent polygon becomes better drained (Jorgenson et al., 2006). Thermal erosion gullies often develop along thawing ice wedges, channelize surface water flow, and can lead to drying of adjacent soils (Godin et al., 2014). Thaw slumps and activelayer detachment slides are common on slopes with an icerich intermediate layer or where buried glacial ice is abundant (Kokelj and Jorgenson, 2013). This disturbance quickly removes surface organic layers, which can be exported to rivers and lakes or re-buried in thick debris lobes. The fate of this material is uncertain, but some portion may be restabilized in new environments. Furthermore, in some cases, it appears that stabilization and recovery of newly exposed surfaces can occur within several decades as changes in vegetation composition and ecosystem biogeochemistry promote greater productivity and relatively rapid accumulation of new organic matter (Pizano et al., 2014). 


\section{Cryopedogenesis}

Cryopedogenesis refers to soil formation processes as affected by freezing temperatures and freeze-thaw processes or cryogenic processes. Some of the most important direct effects result from the physical barrier the permafrost zone imposes on (1) water movement and biogeochemical processes at low temperatures and (2) the expansion and contraction of the active layer during the formation and melting of seasonal ice. Permafrost also exerts seasonal cooling effects on the bottom of the active layer, which affects ice formation and the freeze up of the active layer.

\subsection{Biochemical processes at low temperatures}

The accumulation of soil organic matter (SOM) in permafrost regions is enhanced by two factors that slow the rate of decomposition: (1) low temperatures and (2) anaerobic conditions caused by high moisture content in the active layer (Kaiser et al., 2007; Rodionov et al., 2007). Cool soil temperatures also slow chemical alteration of soil minerals and biological activity. The zero-curtain zone of the active layer provides favorable conditions for heterotrophic soil respiration during the late fall to early winter. Thus, appreciable gas fluxes have been measured on the snow surface during winter (Zimov et al., 1993, 1996; Fahnestock et al., 1999). It is likely that frost cracks provide passages for gases to reach the atmosphere as there is often a strong pulse of gases during early spring thaw. Under saturated conditions, the processes and rates of SOM degradation involve complex biogeochemical interactions that can lead to release of either methane or carbon dioxide (Megonigal et al., 2004). While such processes have been shown to occur at low temperatures (Gilichinsky and Rivkina, 2011), efforts to understand the dominant microbial processes and abiotic factors controlling these processes and their interactions in permafrost soils are currently the subject of increasing research efforts (e.g., Rivkina et al., 2007; Wagner et al., 2007; Lipson et al., 2013; Frank-Fahle et al., 2014).

In addition, mineral elements can be reduced even at subzero temperatures. Most commonly manganese $(\mathrm{Mn})$ and iron $(\mathrm{Fe})$ are first reduced followed by sulfur and then carbon dioxide, with reduction of the latter producing methane (Patrick and Jugsujinda, 1992). Elements like Mn and Fe in minerals are reduced by microbial processes and can be released into the aquatic system (Lipson et al., 2010). When the concentration of SOM is high, reduced $\mathrm{Fe}\left(\mathrm{Fe}^{2+}\right)$ in soil solution is rapidly oxidized upon contact with air, forms a poorly ordered $\mathrm{Fe}^{3+}$ oxide film on water surfaces, and eventually precipitates as orange-colored deposits called ferrihydrite (Schwertmann and Taylor, 1989). The hydromorphism also results in the gleyed color of the mineral matrix in the lower active layer due to Fe reduction (Ping et al., 1993, 2008a).

\subsection{Soil structure in the active layer}

Cryogenesis commonly results in some unique soil structures that are limited to the Arctic, sub-Arctic, Antarctic, sub-Antarctic, and alpine regions. Ice formation, as the active layer refreezes in the fall and winter, varies depending on the conditions that occur in different parts of the active layer. This variation results in the development of an assortment of soil cryogenic structures. On the exposed ground surface of silty mineral soils with no (or only thin) surface organic horizons, crumb and granular structures develop due to needle ice formation (Ping et al., 2008a). Ice crystals form on frozen soil particles or structural units near the surface when water is drawn from below to form or build the needle-like ice crystals that lift and move soil particles or structural units (Brink et al., 1967). Under snow cover, sublimation ice can build near the surface from water vapor in the soil atmosphere, and this can also produce needle ice. In this process, small amounts of surface-accumulated organic matter can be mixed with the top few centimeters of mineral soil - promoting aggregation, disrupting root establishment, and favoring biotic crust formation (Pawluk, 1988; Michaelson et al., 2008, 2012). In the High Arctic, where vegetative and snow cover are scant, a persistent net of soil surface cracks form due to freeze-desiccation contraction, creating small frost polygons that in turn produce microenvironments that support different vegetation communities (Walker et al., 2008). In areas where snow banks occur on slopes, the micro-cracking and vegetation pattern can interact with erosion and deposition patterns to form small $<1 \mathrm{~m}$ diameter turf hummocks (Tarnocai et al., 2006; Broll and Tarnocai, 2002; Lewkowicz, 2011). But, these small polygons and hummocks caused by frostdesiccation cracks result in little cryoturbation, largely due to rapid freeze up and insufficient moisture to develop segregated ice during the freeze up. These surface cryogenic processes are most important on the surface of exposed mineral soils, such as those of active frost boils in the Low Arctic and more generally across the landscapes of the High Arctic.

\subsection{Soil structure in the upper permafrost}

As mentioned above, the transient layer is the upper zone of permafrost that has formed more recently. This layer can be thawed during extremes of the climate cycle but remains frozen most years. For this reason, the transient layer may be more ice rich and be similar in ice and soil structures to the lower active layer when it is frozen. Angular blocky, lenticular, or platy soil structures are common. The upper permafrost below the intermediate layer, however, is usually devoid of visible or larger ice bodies or lenses. Rather, it is ice cemented or has porous visible or invisible ice crystals (Murton and French, 1994). The cryostructure of upper permafrost deposits is often structureless. The most common exceptions occur in permafrost landscapes that have developed for long periods of time or under many thaw-lake cycles or periodic 
depositional cycles, where the permafrost has moved steadily upward encompassing many previous transient and active layers (Hinkel et al., 2003). Permafrost soils can contain very large proportions of ice in the upper-permafrost horizons (the transient and intermediate layers of Shur, 1988). Investigations over large exposed areas of Alaska's Arctic coastline found the overall average ground ice content of permafrost soils to be $77 \%$ by volume in the upper few meters of soil, ranging from $89 \%$ in Yedoma formations to $43 \%$ in eolian deposits (Shur and Zhestkova, 2003; Kanevskiy et al., 2013). Schirrmeister et al. (2008) investigated the characteristics of the Yedoma suite in northern Siberia and offshore islands and found that gravimetric ice contents averaged 60-120\% in sequences of permafrost soils. Although most of the studies on cryostructure are focused on its physical aspects, cryostructure also has a role in soil biogeochemical processes. As the unfrozen water in ice lenses or ice layers in the cryostructure engage in heat and mass transfer in the winter (Romanovsky and Osterkamp, 2000), unfrozen water can serve as a channel for biological activity and thereby affect carbon cycling during winter months (Fahnestock et al., 1999).

\subsection{Classification of permafrost soils}

Permafrost-affected soils are referred to as Cryosols in both the International Union of Soil Sciences (IUSS) World Reference Base (WRB) (IUSS Working Group WRB, 2014) and the Canadian soil classification system (Soil Classification Working Group, 1998), Gelisols in the US system (Soil Survey Staff, 1999), and permagelic suborders in the Chinese system (Gong, 2001). The Russian system has no equivalent for Cryosols/Gelisols. In the new Russian system (Shishov et al., 2004), the presence of permafrost (within 1 or $2 \mathrm{~m}$ of the surface) and cryoturbation is taken into account at lower taxonomic levels. Despite differences in nomenclature and the properties used for classification, these systems share the basic requirement of the presence of permafrost at a certain depth, generally within $2 \mathrm{~m}$ of the surface. However, these systems differ substantially in their classification hierarchy. In the WRB and Russian systems, the genetic lineage or soil material type (such as organic vs. mineral) supersedes soil thermal regimes. For example, organic soils (Histosols) key out first and those with permafrost key out in the subclass as Cryic Histosols. But, in the Canadian and US systems, Cryosols and Gelisols, respectively, key out first because permafrost is recognized as the controlling factor in land-use interpretation and ecosystem functions.

Gelisols of the US classification system have three suborders: Histels, Turbels, and Orthels. Histels are organic soils, Turbels are mineral soils affected by cryoturbation, and Orthels are mineral soils lacking cryoturbation (Soil Survey Staff, 1999). Examples of each great group in the High and Low Arctic and boreal regions are shown in Fig. 3. Gelisols are ubiquitous throughout the continuous permafrost zone of the northern circumpolar Arctic region. In this zone, Gelisols commonly form in lowlands with restricted drainage that favor near-surface permafrost, but Gelisols also form in welldrained upland sites where the permafrost is deeper (Rieger, 1983; Ping et al., 2004; Li et al., 2008). Within the discontinuous and sporadic permafrost zones of the boreal regions, the slope and aspect of uplands and mountains play a controlling role in distributions of permafrost and Gelisols (Péwé, 1975; van Cleve et al., 1983; Ping et al., 2005a). In the Southern Hemisphere, permafrost and Gelisols occur on the Antarctic continent, on the sub-Antarctic islands, and in mountain areas (Beyer et al., 1999, 2000; Blume et al., 1997; Bockheim, 1990; Campbell and Claridge, 2004a, b; Simas et al., 2007; Gilichinsky et al., 2010). However, the organic carbon content of permafrost-affected soils in the southern circumpolar region is extremely low when compared to the northern permafrost region (Bockheim, 1990; Claridge and Campbell, 2004), except for some isolated areas affected by maritime climate in coastal Antarctica and sub-Antarctica (Beyer et al., 1995). Hence, the focus of this review is on permafrost soils of the northern permafrost region.

\section{Modes of soil organic carbon accumulation particular to permafrost soils}

Similar to other soils, the deposition of surface litter, rhizodeposits, and the turnover of belowground biomass are sources of organic carbon inputs to SOM for permafrost soils. The organic matter inputs from the existing plant community are largely deposited in the near-surface active layer. However, one of the most striking differences between permafrost soils and other soils is the large amount of organic carbon stored in the active layer and perennially frozen portions of the soil relative to the annual production of plant biomass. The northern circumpolar region contains about $30-40 \%$ of the global soil carbon pool to a depth of $3 \mathrm{~m}$, yet the region covers just $15 \%$ of the global land surface and supports only 10-20\% of the global vegetation carbon pool (Jobbágy and Jackson, 2000; McGuire et al., 2009; Hugelius et al., 2014; Köchy et al., 2014). The disproportionate ratio of soil carbon to plant biomass carbon in the permafrost region is due to the slow decomposition rates for organic matter under the low temperatures and often saturated (thus reducing) conditions in these soils (Hobbie et al., 2000; Davidson and Janssens, 2006; Ping et al., 2008b, 2010). However, in permafrost soils, other processes, such as crystal and massive ice formation, freeze cracking, freeze jacking, diaparism, and gelifluction can result in deformation and displacement of soil materials within the profile. The deformation and displacement of soil materials caused by these general processes are commonly referred to as cryoturbation (Williams and Smith, 1989; Bockheim and Tarnocai, 1998; French and Shur, 2010). Cryoturbation does not cause direct input of organic carbon to soils; instead, it displaces and redistributes SOM within the active layer of the soil profile. Over time and with changing conditions, cry- 


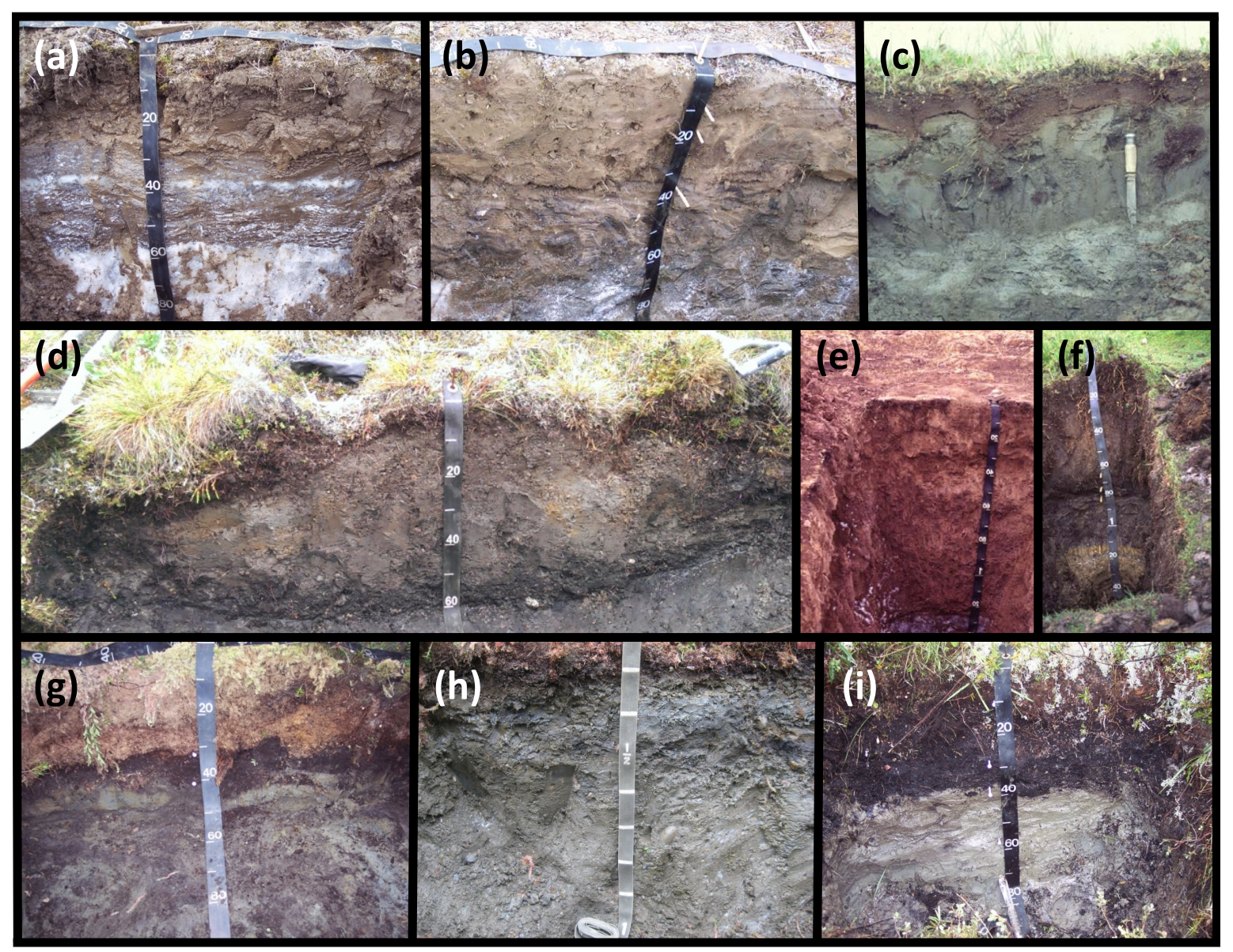

Figure 3. Examples of permafrost-affected soils from different areas: (a) Glacic Aquiturbel formed in weathered shale with small patterned ground features (polar desert), ice wedge at $58 \mathrm{~cm}$, Ellef Ringes Island, Nunavut, Arctic Canada; (b) Haploturbel associated with a nonsorted circle, formed in weathered siltstone (High Arctic), Mould Bay, Arctic Canada; (c) Ruptic-Histic Aquiturbel formed in Yedoma deposit under nonacidic tundra, Mys Chukochi, Northern Yakutia, Russia; (d) Ruptic Histoturbel associated with a nonsorted circle, formed in loess over Tertiary glaciofluvial deposit under tussock tundra, Arctic Alaska; (e) a well-drained Haploturbel formed in weathered sandstone under alpine tundra, northern-central Qinghai-Tibet Plateau, China; (f) Histel formed in wet Kobrecia meadow (note the limnic layer at $112 \mathrm{~cm}$ ), Qinghai-Tibet Plateau, China; (g) Histoturbel formed in late Pleistocene glaciofluvial deposit under boreal forest, northern Alaska; (h) Aquorthel formed in loess deposit under boreal forest, central Alaska; and (i) Histel formed in bog, central Alaska. Soils shown in (a), (b), (f), (h), and (i) are formed in epigenetic permafrost and soils shown in (c), (d), (e), and (g) are formed in syngenetic permafrost.

oturbated organic matter in the active layer can become encased in permafrost by processes associated with either intermittent burial or syngenetic permafrost growth (Schirrmeister et al., 2002a, 2011a; Kaiser et al., 2007; Ping et al., 2008a, b). The unique feature of most permafrost-affected soils is the storage of large quantities of this surface- and near-surface-produced SOM at depth - mainly in Turbels, which account for $35 \%$ of the areal extent and $46 \%$ of the organic carbon stocks of all Gelisols (Hugelius et al., 2014). However, cryoturbation has no (or only a minor) effect on organic carbon storage in Histels, Orthels, and the large areas of Histosols in the northern circumpolar region. Nevertheless, other processes can also redistribute and stabilize carbon in these permafrost-affected soils. For example, dissolved organic carbon that is transported from the active layer to the permafrost table can accumulate there due to "cryochemical precipitation" (Ostroumov et al., 2001; Gundelwein et al., 2007).

\subsection{Cryoturbation}

Cryoturbation is the term used to describe the lateral and vertical displacement of soil during seasonal and/or diurnal freezing and thawing (French, 1988). The genesis of cryoturbation has been attributed to loading, cryohydrostatic pressure and cryostatic pressure, and diaparism (Washburn, 1973; Rieger, 1983; French, 1988; Vandenberghe, 1988; Swanson et al., 1999). However, Mackay (1980) diffused the commonly accepted cryostatic pressure theory and proposed an alternative equilibrium model as a mechanism for cryotur- 
bation in hummocks. His equilibrium model was based on field and laboratory evidence for cell circulation within the confines of bowl-shaped frost tables under hummocks. He explained the upward displacement of material in a hummock by a gravity-induced cell-like movement caused by the freeze-thaw of ice lenses at both the top and bottom of the active layer. The cell circulation occurs because the top and bottom freeze-thaw zones have opposite curvatures, as described by Shilts (1978). Under this mechanism, the period of greatest activity occurs in early summer at the top of the active layer and in late summer at the bottom. In contrast, activity induced by cryostatic pressure would be greatest during the early winter freeze-back period, but Mackay (1980) could not find any theoretical, experimental, or field evidence to support that mechanism for hummocks. Hummocks are nonsorted circles that have uniform soil texture inside and outside the circle and are one of the most widely distributed forms of patterned ground in permafrost regions (Washburn, 1973, 1980). However, cryoturbation also manifests in sorted circles. Kessler et al. (2001) used a similar circulation model to describe a mechanism for sorted circle formation in areas where a layer of soil underlies a uniform layer of stones. They proposed that frost heave deforms the stone-soil interface and that this causes local instabilities, where soil plugs begin to form. Through a variety of transport mechanisms driven by freeze-thaw cycles, the soil plugs grow upward as soil is drawn in from surrounding areas. The soil plugs develop into sorted circles as they contact the ground surface, simultaneously elevating a surrounding circle of stone or gravel. Once formed, sorted circles are maintained by continued dynamic circulation within the soil and stone domains.

Indeed, the most striking cryoturbation features are associated with patterned ground (especially nonsorted and sorted circles) and include broken, involuted or warped horizons within the soil profile (Tarnocai and Smith, 1992; Ping et al., 2008a, 2013). These features are caused by differential frost heave processes in the soils. Commonly, circle centers are devoid of vegetation or are only sparsely vegetated. Whereas, the areas outside and at the margins of circles have tundra vegetation with thick organic horizons (Fig. 4). Due to the lack of surface thermal insulation, the mineral-dominated circles tend to thaw faster and deeper, resulting in deeper active layers, but they also freeze faster. In contrast, areas outside the circle, which are insulated by vegetation cover and organic layers, have shallow active layers and tend to have higher soil moisture content during thaw cycles (Shilts, 1978). These factors contribute to the development of the bowl-like frost table central to the Mackay (1980) equilibrium model described above. Because the mineral-dominated circles freeze faster, they draw available water from the circle margins to form ice lenses, which displace greater volumes of soil in circle centers. Meanwhile, freeze contraction allows cracks or voids to develop around the circles. As a consequence, greater heaving and deformation occurs within the circles than in the adjacent insulated inter-circle

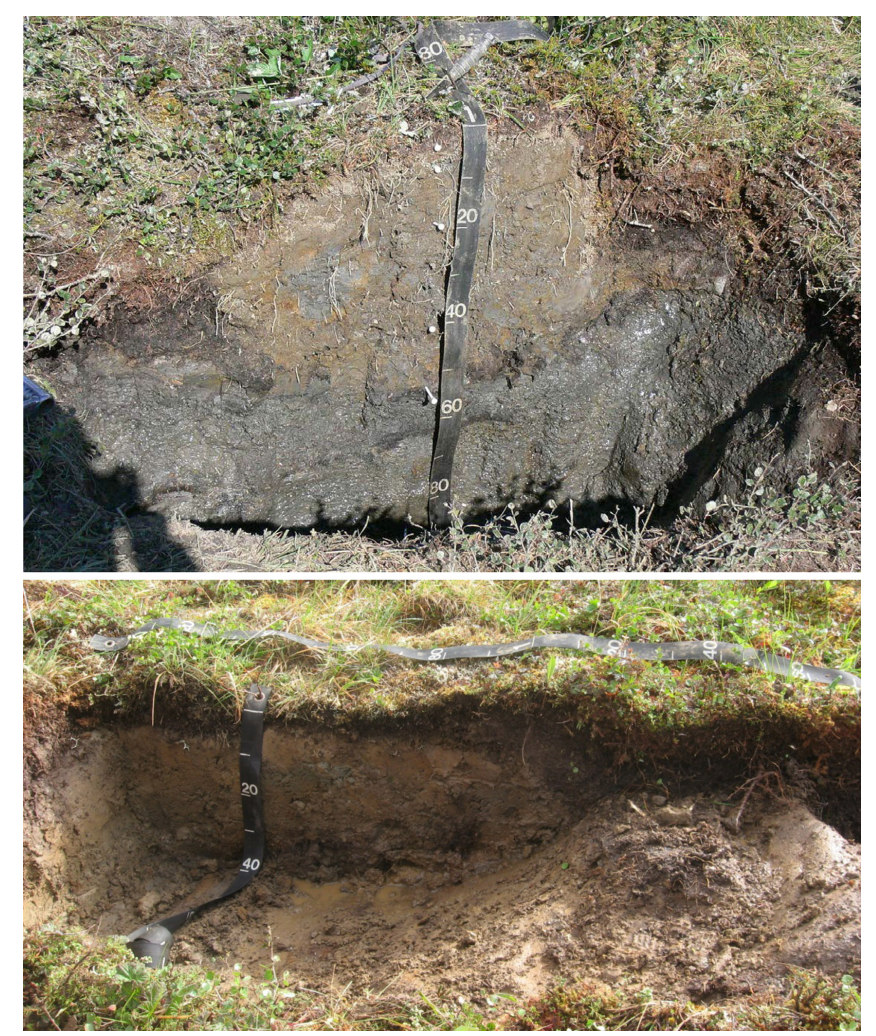

Figure 4. Cryoturbated soil profiles of the thawed active layers of an earth hummock (top) and a nonsorted circle (bottom). Note the distribution of organic matter in the low micro-topographic positions and the insulating effect of the organic horizon on thaw depths.

soil. Frost heave in extreme cases can cause the surface to heave as much as $20 \mathrm{~cm}$ in circles compared to $3 \mathrm{~cm}$ in vegetated soils surrounding the circles (Romanovsky et al., 2008). This differential frost heave often causes the organic mat and, in some cases, the vegetative cover, to be entrapped in the cracks along the edge of patterned ground features. From there, this material is frost-churned down with the circulation described by Mackay (1980) from the depressed intercircle zone to the lower active layer under the circle, where it eventually can become part of the upper permafrost (Ping et al., 2008a). Generally, nonsorted circles form in fine-textured (loamy) soils, particularly silt loam soils. With increasing clay contents, the centers of such circles tend to be more elevated. Circles with elevated centers are termed "earth hummocks", with hummock height directly related to clay content (Ping et al., 2008a).

The importance of cryoturbation in soil formation has long been studied and stressed by soil scientists and geocryologists. Classic examples of these studies were carried out in the 1970s in the Canadian Arctic by Tedrow (1974), Pettapiece (1974), Tarnocai and Zoltai (1978), and Mackay (1980), and summarized by Tarnocai and Smith (1992). These researchers found that the depth of the permafrost table is inversely related to 
the surface microtopography; i.e., the active layer is deepest in the center of the earth hummock and shallowest in the depressions around the hummocks. They also noted that buried and discontinuous organic horizons occurred at depth, and attributed this "burial" phenomenon to cryoturbation. Concurrently in northeastern Russia, Makeev and Kerzhentsev (1974) also found similar accumulation of cryoturbated organic matter at the permafrost table, which often occurs at depths of 100 to $200 \mathrm{~cm}$. Gubin and Lupachev (2008) found a concentrated layer of organic matter in the upper part of the transient layer under earth hummocks. Rieger et al. (1979) also recognized the occurrence of "black streaks of frostchurned organic matter" at depth and discontinuous surface organic horizons in association with nonsorted circles in the tundra of Arctic Alaska. This work led to the creation of the subgroup of "Ruptic-Histic" in the US taxonomic system (Soil Survey Staff, 1975). Later, more detailed pedological studies in Arctic Alaska asserted that cryoturbation is the primary factor controlling the amount of carbon sequestered in the soils of tundra dominated by nonsorted circles (Bockheim et al., 1998; Ping et al., 1998, 2008b; Bockheim and Hinkel, 2007). Thus, the presence/absence of cryoturbated features was adopted as differentia for the Turbel suborder of Gelisols in US taxonomy (Bockheim and Tarnocai, 1998, Ahrens et al., 2004) and for the prefix of Cryosols in the WRB (IUSS Working Group WRB, 2014). However, these phenomena are not limited to the continuous permafrost zone. Cryoturbation and carbon translocation/sequestration associated with sorted circles, stripes, and solifluction are also commonly found in landscapes affected by periglacial processes, such as alpine environments in the boreal regions of Alaska (Geisler and Ping, 2013), Mongolia (Maximovich, 2004), and southern Siberia (Gracheva, 2004). Deeply subducted organic masses are even found in rocky permafrost soils lacking surface evidence of patterned ground (Jorgenson et al., 2013). Furthermore, when permafrost is absent under current climate conditions, cryoturbated profiles are often still present as remnants of past permafrost environments (Munn, 1987; Rieger, 1983).

Redistribution of organic matter within the soil profile due to cryoturbation is most common in the Arctic, where patterned ground processes are active - such as sorted and nonsorted circles and ice-wedge polygons (Washburn, 1973; Michaelson et al., 2008; Walker et al., 2008; Kanevisky et al., 2011; Zubrzycki et al., 2013; Ping et al., 2008b, 2014). In early studies, SOC stocks were measured only at shallower depths - mostly limited to the rooting zones at depths less than $50 \mathrm{~cm}$, due to logistics (Brown, 1969; Everett and Brown, 1982). However, as concerns about global warming increased, this raised fears that the organic carbon stored in permafrost-region soils might become a source of rather than a sink for atmospheric carbon (Oechel et al., 1993). Consequently, a series of studies was conducted in the northern circumpolar regions to explore the depth distribution of stored biogenic carbon in Gelisols (Michaelson et al., 1996, 2008,
2013; Ping et al., 1998, 2008b; Bockheim and Hinkel, 2007; Bockheim et al., 1999; Tarnocai et al., 2009; Hugelius et al., 2010, 2013a, b; Strauss et al., 2012, 2013). Generally, on gentle to moderate slopes of glaciated uplands, SOM was cryoturbated to depths of mostly 80 to $120 \mathrm{~cm}$. But, cryoturbated SOM was found to reach depths of $3 \mathrm{~m}$ or more on exposed ridge tops where vegetation is sparse and protection from snow cover during winter is lacking (Michaelson et al., 1996), on floodplains (Shur and Jorgenson, 1998), in thaw-lake basins (Hinkel et al., 2003; Ping et al., 2014), and in degraded permafrost in the boreal region (Jorgenson et al., 2013). Most of these mineral soils with cryoturbated SOM and broken surface organic horizons are classified as Turbels (Turbic Cryosols). But, in the poorly drained valleys or basins among the hilly uplands, thick organic horizons $(>40 \mathrm{~cm})$ can build up due to fen or bog formation, and these soils are classified as Histels (Cryic Histosols) (Ping et al., 2004, 2005a).

Ping et al. (2008b) measured SOC stores along a northsouth transect through five bioclimatic subzones from the High Arctic to the boreal regions in North America as part of a larger study investigating the interrelationships between patterned ground formation and vegetation zonation (Walker et al., 2008). As the patterned ground transitioned from simple frost cracking in the High Arctic to well-formed nonsorted circles in the Low Arctic, the land-cover types changed from polar desert to tundra to shrub tundra, with increased dominance of vascular plants in the south (Walker et al., 2008). Ping et al. (2008b) found that SOC stocks were directly related to biomass production but that the proportion of cryoturbated carbon did not follow the same trend. Rather, the proportion of cryoturbated carbon stored in the upper permafrost reached a peak near the middle of the transect, where tussock tundra dominates the landscape, and then dropped off further south, where shrub tundra becomes dominant (Michaelson et al., 2008; Ping et al., 2008b). This trend corresponds to reduced frost heave and cryoturbation under shrub tundra because the taller vegetation canopy, thicker ground moss layer, and increased snowfall provide greater thermal insulation (Rodionov et al., 2007; Kade and Walker, 2008; Walker et al., 2008).

\subsection{Deformation by massive ice formation}

Ice-wedge polygons, with diameters ranging from a few meters to more than $20 \mathrm{~m}$ across, dominate the landscapes of the Arctic coastal plains, which are widespread lowlands throughout the northern circumpolar region. Ice-wedge polygons also dominate river floodplains, valleys, lowland areas and thermokarst depressions in Arctic foothills and the subArctic, e.g., interior Alaska, northern Canada, and central Yakutia, Russia (Péwé, 1975; French, 2007; Schirrmeister et al., 2011b; Strauss et al., 2012; Zubrzycki et al., 2013). During ice-wedge development, soils on both sides of the ice wedge are pushed apart and heaved to form rims on 
both sides, creating a trough between the rims and over the ice wedge that delineates the polygon (Fig. 2). The polygon center is less affected and remains flat or slightly lower than the rims. At this developmental stage, the polygons are flat- or low-centered, where the trough (and often the center) is wet during the growing season. Three different main soil types have been observed to develop across this microtoposequence: (1) organic or organic-rich soils over the ice wedge (generally less than $50 \mathrm{~cm}$ across) in the polygon trough (Glacistels), (2) cryoturbated soils along the polygon rims (Histoturbels or Aquiturbels), and (3) soils usually lacking cryoturbation in flat or low polygon centers (Aquorthels, Historthels). However, with time, the ice wedges can degrade, forming deep troughs (Jorgenson et al., 2006). Relatively, polygon interiors then become high centered, surface cracking increases, and greater cryoturbation associated with the cracks leads to formation of soils (Histoturbels) with greater organic matter accumulations (Ping et al., 2011, 2014; Zubrzycki et al., 2013).

\subsection{Intermittent burial and syngenetic permafrost}

Intermittent burial by eolian, alluvial, colluvial, and lacustrine sediments can lead to accumulation of significant SOC stocks in these depositional environments (Shur and Jorgenson, 1998; Schuur et al., 2008; Tarnocai et al., 2009; Grosse et al., 2011; Schirrmeister et al., 2008, 2011b; Zubrzycki et al., 2013). These processes are often accompanied by syngenetic permafrost growth, where the upward growth of the permafrost surface follows the accumulation of sediments and peat layers at the surface (Shur, 1988).

Deltas and thaw lakes with ice-rich permafrost are abundant along the Arctic coastal plains, such as at Barrow in northwestern Alaska (Hinkel et al., 2005), the Colville Delta in northern Alaska (Shur and Jorgenson, 1998; Ping et al., 2011) and the Lena River Delta in northern Russia (Boike et al., 2013; Zubrzycki et al., 2013). In the Colville Delta, buried organic soils are found as deep as $3 \mathrm{~m}$ (Shur and Jorgenson, 1998). In addition to Arctic coastal plains, thaw lakes are also common in the sub-Arctic, such as interior Alaska (Péwé, 1975), northern Canada (Sannel and Kuhry, 2011), and several areas in Russia (Grosse et al., 2013).

Thaw lakes and drained thaw-lake basins are prevalent on flat landscapes in the Arctic and boreal regions where ground ice is sufficiently abundant to allow the surface to thaw, collapse, and be filled with water to form shallow $(<2 \mathrm{~m})$ and deep $(>2 \mathrm{~m}$ ) lakes. Thaw lakes are most abundant on icerich, fine-grained deposits, such as abandoned floodplains, colluvial lower slopes and basins, peatlands, and lowland loess deposits (Veremeeva and Gubin, 2009; Grosse et al., 2013; Jorgenson, 2013). The age of thaw lakes can be extremely variable with some thaw lakes in Yedoma persisting since the late Pleistocene (Grosse et al., 2013, Kanevskiy et al., 2014), while others are newly formed. Veremeeva and Gubin (2009) identified two stages of active thaw-lake for- mation in Northern Russia; one during the early Holocene around 9000 to 8000 years BP and the second one during the late Holocene around 5000 to 4000 years BP. Formation of these lakes has been largely attributed to thermokarst and thermal erosion processes related to past and modern climate changes and more recently to land use. In addition, not all lakes in permafrost regions are thaw lakes; some can simply be abandoned channel lakes, inter-dunal lakes, or impoundments in depressions of undulating surficial deposits (Jorgenson et al., 2006). In many Arctic coastal plain regions, there are overlapping lakes and lake basins, which have been attributed to "thaw-lake cycles" as short as 3000 years in northern Alaska (Hinkel et al., 2003). However, Jorgenson and Shur (2007) argued that ice aggradation and degradation are generally too slow to account for this. They proposed that the process is less cyclical and more evolutionary throughout most of the Arctic coastal plain of Alaska, with secondary thaw lakes being a common outcome of developmental sequences that depend on factors such as topography, reworking of surficial deposits, drainage, and ground ice conditions. In some cases, soils formed in drained-lake basins reflect multiple thaw episodes, as evidenced by the presence of multi-layered organic-mineral horizons with cryoturbated organic matter to depths of 2-4 m (Fig. 5) (Ping et al., 2014; Kanevskiy et al., 2014). Thaw lakes can also form in landscapes where there are no ice wedges. For example, thaw lakes are commonly associated with the degradation of palsas and peat plateaus in sub-Arctic peatlands, such as those observed in the northern boreal region of Alaska (Brown and Kreig, 1983). As a consequence of thaw-lake dynamics, large SOC stocks can accumulate - as high as $90 \mathrm{~kg} \mathrm{C} \mathrm{m}^{-2}$ in profiles up to $3 \mathrm{~m}$ deep (Ping et al., 2011). Much of the organic matter in the central portions of drained-lake basins is derived from limnic sediments comprised of algal material and detrital peat eroded from collapsing lake shores (Jorgenson, 2013).

Extremely ice-rich silt deposits of Pleistocene age, known as Yedoma or Ice Complex, are particularly noteworthy because of the significant stocks of "fossil" organic carbon (Schirrmeister et al., 2011a). These deposits (average depth $\sim 20-25 \mathrm{~m}$ ) developed during the late Pleistocene in unglaciated areas of the Beringia, including northern Siberia, Arctic and Interior Alaska, and the Yukon Territory, Canada (Zimov et al., 2006; Froese et al., 2008; Schirrmeister et al., 2002a, b, 2011b; Kanevskiy et al., 2011; Vonk et al., 2012). Yedoma deposits are polygenetic accumulations of eolian or water-borne origin that settled in the interglacial periods under syngenetic conditions when permafrost was already present or in an environment that already experienced sub-zero temperatures for most of the year (Kanevskiy et al., 2011; Schirrmeister et al., 2002a, b, 2011b, 2013; Strauss et al., 2012). The volumetric ice content of Yedoma can be as high as $80-90 \%$, including both segregated ice within soil and massive ice wedges that can reach depths of $50 \mathrm{~m}$ or more (Kanevskiy et al., 2013). Mineral horizons 


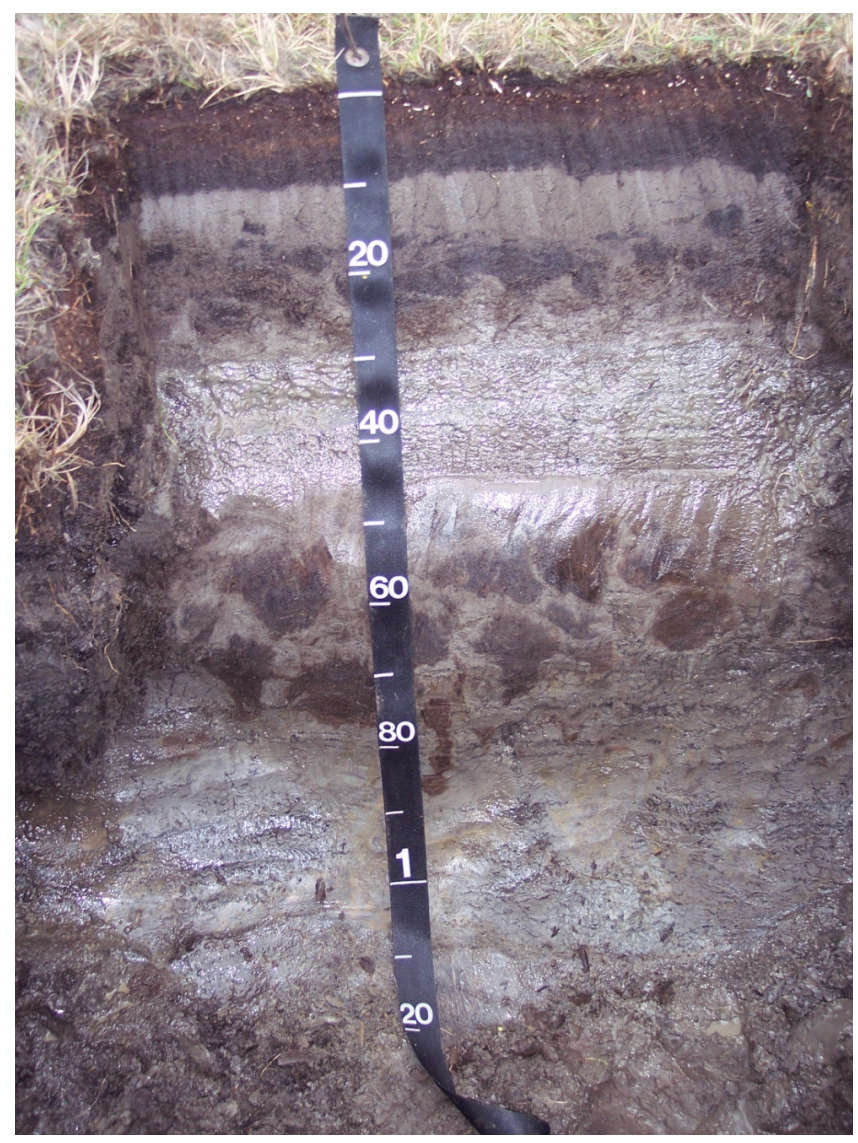

Figure 5. Gelisol profile from the Arctic coastal plain of northwestern Alaska exhibiting a complex stratigraphy developed through a sequence of different environments coupled with cryoturbation caused by freeze/thaw/heave forces. The strata suggest that (1) old coastal plain sediments below $80 \mathrm{~cm}$ thawed and collapsed into a thaw lake as indicated by the mixed-up sediments with scattered fragmental peat chunks; (2) after drainage, an organic mat developed at 50 to $80 \mathrm{~cm}$; (3) this mat was flooded or collapsed within the lake basin and was covered by limnic silts at $30-50 \mathrm{~cm}$; (4) after a second drainage, another organic mat covered the limnic silts at 15 to $30 \mathrm{~cm}$; (5) windblown eolian silt covered this mat at $10-16 \mathrm{~cm}$; and (6) a final organic mat developed at the surface. The fluctuating and rising permafrost table disrupted the underlying organic mats.

in Yedoma typically contain over $70 \%$ silt, although sandy deposits also occur. Fast sedimentation rates and simultaneous freezing often buried and preserved organic matter that is potentially more decomposable than that of non-permafrost mineral soils. The concentrations of organic carbon in these deposits average 1-5\% (Strauss et al., 2013), but concentrations can reach $15 \%$ in peaty horizons within some deposits (Schirrmeister et al., 2002b). Strauss et al. (2013) estimated an organic carbon pool of $83(+61 /-57) \mathrm{PgC}$ for the Yedoma deposits of Siberia and Alaska, with an average organic carbon density of $19(+13 /-11) \mathrm{kg} \mathrm{C} \mathrm{m}^{-3}$ that was reduced to $10(+7 /-6) \mathrm{kg} \mathrm{C} \mathrm{m}^{-3}$ when ice-wedge volumes were included in the estimate.
The large ice content of Yedoma makes this soil particularly vulnerable to climate warming, and deep thermokarst lakes are common on the Yedoma landscape. Some thermokarst lakes eventually turn into drained basins, or "alases", a Yakutian term for thermokarst basins with steep slopes and flat floors. Alas formation passes through a sequence of landforms - lake, swamp, wet meadow, and grassland - with associated soil types (Czudek and Demek, 1970; Veremeeva and Gubin, 2009; Desyatkin, 2008). In the intermediate stage, permafrost organic soils (Histels) were found in alases at Duvaany Yar, the extensively studied Yedoma formation along the Kolyma River upstream from Cherskiy (Smith et al., 1995), and in northern Alaska (Kanevskiy et al., 2011). Morgenstern et al. (2013) suggested that alas formation was most extensive across the coastal lowlands of eastern Siberia due to abrupt thaw-lake drainage during the early Holocene. However, on a local scale and often within primary alases, more dynamic but less intensive thermokarst processes during the late Holocene have shaped the modern thermokarst terrain, which continues to evolve in response to present-day climatic and land-use changes.

\section{Quantity of organic carbon in permafrost soils}

Major efforts to estimate global SOC storage during the twentieth century yielded values ranging from 400 to $9120 \mathrm{PgC}$ stored in soils worldwide (Amundson, 2001). Amundson (2001) calls attention to the wide variation in the amounts of soils data, analyzed depths, and summation methods used in these early analyses of the global SOC pool. Some estimates applied overall soil averages to the entire land surface (Rubey, 1951), others averaged SOC storage according to ecosystem types (Schlesinger, 1977; Post et al., 1982; Jobbágy and Jackson, 2000), while others were based on soil maps and soil taxonomy (Atjay et al., 1979; Bohn, 1982; Eswaran et al., 1993). However, the influence of permafrost on SOC storage was not directly recognized until relatively recently in studies such as Tarnocai and Lacelle (1996), Tarnocai (1998), Michaelson et al. (1996, 2013), Ping et al. (2008b), Hugelius et al. (2010), Bliss and Maursetter (2010), Johnson et al. (2011), and Mishra and Riley (2012) for Alaska and North America; Stolbovoi (2002), Kuhry et al. (2002), Rodionov et al. (2007), Hugelius (2012), Schirrmeister et al. (2011a), and Zubrzycki et al. (2013) for Eurasia; and Tarnocai et al. (2009) for the entire northern circumpolar region. Indeed, the Gelisol order of Soil Taxonomy was only established in 1999 (Soil Survey Staff, 1999).

As more soil pedon data became available, especially pedons evaluated for SOC storage, estimates of the permafrostregion SOC pool increased substantially - primarily due to a fuller accounting of deeper cryoturbated carbon and permafrost carbon stocks. As an example, Jobbágy and Jackson (2000) estimated that only $294 \mathrm{Pg} \mathrm{C}$ were stored at 0 $3 \mathrm{~m}$ depth in the boreal forest and tundra biomes combined, 
whereas Tarnocai et al. (2009) estimated $1024 \mathrm{Pg} \mathrm{C}$ stored at 0-3 $\mathrm{m}$ for the northern circumpolar permafrost region. Although the estimate by Tarnocai et al. (2009) was based on about 1700 total pedons, only 25 of these pedons encompassed the full 0-3 m depth. At present, the largest spatially distributed soils data set from the northern circumpolar region is the Northern Circumpolar Soil Carbon Database (NCSCD), which was initially developed for the Tarnocai et al. (2009) estimate. The NCSCD was recently updated with new data for soil depths of $1-3 \mathrm{~m}$ as well as deeper Yedoma and deltaic-alluvium deposits (Hugelius et al., 2013a, b). Hugelius et al. (2014) used the updated NCSCD to produce the current best overall estimate of $1307 \mathrm{PgC}$ stored in permafrost region soils ( $0-3 \mathrm{~m}$ depth together with carbon in the deeper Yedoma and deltaic deposits). Of this total, roughly two-thirds ( $822 \mathrm{Pg} \mathrm{C}$ ) is estimated to occur in permafrost. However, the overall estimate has a substantial uncertainty range (1140-1476 Pg C) and significant data gaps. Among the reasons for the large uncertainty range are the remoteness and vastness of the region $\left(17.8 \times 10^{6} \mathrm{~km}^{2}\right.$ or $16 \%$ of global soil area). In the updated NCSCD database, the carbon estimates at 0-1 $\mathrm{m}$ depth were derived from 1778 pedons. However, deeper soils were represented by only 341 Gelisol pedons and 177 pedons of non-permafrost soils at 1$2 \mathrm{~m}$ and by 246 Gelisol pedons and 105 non-permafrost soil pedons at 2-3 m (Hugelius et al., 2014). Although these numbers constitute a significant improvement over the deep soil pedons available for the Tarnocai et al. (2009) estimate, the data are still quite limited considering the overall size of the region.

In addition to the low sampling density due to difficulties associated with remote access and the vast extent of the circumpolar permafrost region, there are technical and sampling challenges unique to Gelisols. These challenges can contribute to increased variability and decreased confidence in SOC storage calculations and the overall carbon stock estimates for Gelisols. However, these issues were not accounted for by Hugelius et al. (2014) in their uncertainty estimates. Two of the more significant technical challenges are the lack of measured soil bulk densities and differences in the methods of SOC determination. Both of these challenges are common in most soil databases, necessitating the estimation of these key soil properties, which are essential to the calculation of SOC storage (Tarnocai et al., 2009; Johnson et al., 2011; Hugelius et al., 2012; Mishra and Riley, 2012).

Modern high-temperature dry-ignition methods provide direct measurements of soil carbon. But, prior to 2000, SOC was commonly estimated indirectly by using variations of the chemical acid-dichromate oxidation method (the WalkleyBlack method), which required calibration or estimation of a recovery factor for the method and group of soils being analyzed. In general, recovery factors have been derived for soils from temperate and warmer environments and have varied substantially. For example, Amacher et al. (1986) reported recovery factors ranging from 0.46 to 0.87 with a mean of 0.71 , which is close to the recovery factor of 0.77 used for the US Department of Agriculture Natural Resources Conservation Service (USDA-NRCS) Alaska soil pedon data set (Soil Survey Staff, 2014). Working with this data set, Michaelson et al. (2013) found that a recovery factor of 0.77 overestimated SOC in Alaska Gelisols by an average of $12 \%\left(R^{2}=0.98\right)$ when compared to analysis by dry-ignition methods. Soil carbon values for other soil orders found in the Alaska data set were overestimated by 3$18 \%$. Yet, these data have been commonly used for pedon carbon assessments of permafrost regions (Tarnocai et al., 2009; Hugelius et al., 2014). Thus, new pedotransfer functions were developed and used by Michaelson et al. (2013) to update the Alaska USDA-NRCS data set because SOC data for $57 \%$ of the pedons were determined only by the chemical dichromate-oxidation method. The problem of overestimating organic carbon concentrations in cold-region soils, such as those found in Alaska, is likely due to the application of recovery factors that were developed for more highly oxidized soils. Overall, the organic matter in cold-region soils tends to be less decomposed and less oxidized compared to more temperate soils. Given a higher proportion of more readily oxidizable (decomposable) organic matter, many cold-region soils could be more completely oxidized by the dichromate-oxidation method, leading to overestimation when the standard recovery factor is used. Higher concentrations of $\mathrm{Fe}^{2+}$ in cool wet soils might also increase estimates by dichromate-oxidation methods. More research into individual soils would be needed to sort these factors out. But, data users should be aware of these aspects of data sets, even though newer data sets are more likely to contain soil carbon data determined by the more direct high-temperature dry-ignition methods.

As an additional complication, SOC concentrations are commonly used to estimate and fill in missing bulk density data. But, for Gelisols, the correlation between SOC concentration and bulk density is poor in the permafrost layer $\left(R^{2}=\right.$ 0.46 ) because of the large and variable ice contents (Michaelson et al., 2013), especially in the often carbon-rich transient layer of the upper permafrost. Ping et al. (1998, 2013) outline state-of-the-art protocols for sampling permafrost soils that address the issues of sampling across pedon cryogenic patterns of variability, calculation of SOC storage in cryoturbated profiles, and the sampling and measuring of bulk density in frozen Gelisol horizons.

Another major issue affecting estimates of the permafrostregion SOC pool is fine-scale vertical and horizontal heterogeneity. Estimates of the vertical distribution of organic carbon stocks in permafrost region soils are extremely important for predicting the amount of SOC that will become vulnerable to mineralization upon top-down thaw or losses due to increased incidence of fire (Koven et al., 2011; Harden et al., 2012). Yet, the content and distribution of organic carbon within the soil profile vary widely among Histels, Turbels, and Orthels (Harden et al., 2012), making this variation a 
major source of uncertainty in current estimates. Furthermore, as described above, patterned ground features can exhibit various combinations of these suborder soils, resulting in large local and landscape heterogeneity. A number of studies have looked at the SOC content of patterned ground features, for example frost boils (Dyke and Zoltai, 1980; Walker et al., 2004; Kaiser et al., 2005; Michaelson et al., 2012), circles (Kimble et al., 1993; Hallet and Prestrud, 1986), stripes (Walmsley and Lavkulich, 1975; Horwath et al., 2008), icewedge polygons (Ping et al., 2014; Zubrzycki et al., 2013), and earth hummocks (Kimble et al., 1993; Landi et al., 2004). In addition to these pedon-scale studies, explicit efforts to account for and incorporate local-scale spatial heterogeneity into sampling designs and upscaling approaches are being explored for the estimation of SOC stocks on landscape or regional scales (Horwath et al., 2008; Hugelius and Kuhry, 2009; Zubrzycki et al., 2013). Hugelius et al. (2011) used the highest resolution upscaling to date of any permafrost SOC study ( $2 \mathrm{~m}$ resolution) and compared local scale heterogeneity vs. regional scale upscaling. Hugelius (2012) also provided an in-depth discussion regarding the topic of upscaling accuracy and spatial resolution in upscaling.

\section{Characterization of the quality and decomposability of organic matter in permafrost soils}

Soil organic matter is a complex and heterogeneous mixture derived mostly from plant litter inputs and microbial residues that exists in various stages of decomposition and associations with soil minerals (Baldock and Skjemstad, 2000; Sutton and Sposito, 2005; Kelleher and Simpson, 2006; Jastrow et al., 2007; Lehmann et al., 2008). Traditionally, the "quality" of SOM (and by inference its intrinsic potential to be further decomposed, transformed and mineralized) has been evaluated by assessing its molecular composition and by applying some type of physical, chemical, or biological fractionation approach to partition the bulk SOM pool into "labile" vs. "recalcitrant" or "stable" forms (Kleber and Johnson, 2010; von Lützow et al., 2007; Simpson and Simpson, 2012). Although the chemical composition of SOM can affect the rate of decomposition, it is now recognized that (1) readily degradable "labile" carbon forms can be stabilized in soil by a variety of mechanisms or conditions that physically or chemically limit microbial access or that impact microbial activity, and (2) even the most "recalcitrant" carbon forms can be mineralized given the "right" conditions (von Lützow et al., 2006; Marschner et al., 2008; Kleber, 2010).

Thus, while precise definitions and standardized measurements of "labile", "recalcitrant", or "stable" SOM pools are not possible, these terms are nonetheless useful in a relative sense for comparing the intrinsic degradation state or potential decomposability of SOM - particularly for permafrostaffected soils. This is because the dominant factors limiting decomposer activity in permafrost soils are the cold and often wet anoxic environments (Davidson and Janssens, 2006). In addition, low soil $\mathrm{pH}$ can limit decomposition rates in some soils (Grosse et al., 2011). Hence, in permafrost soils, organic matter is often preserved in a relatively undecomposed state, both in surface horizons and in buried forms (e.g., peat deposits, cryoturbated organic matter). In addition, much of this organic matter is uncomplexed or only poorly associated with soil minerals (Diochon et al., 2013; Höfle et al., 2013). Furthermore, subzero microbial activity in unfrozen water films can lead to accumulation of easily decomposable, soluble microbial by-products in frozen soils. Plus, soluble organics produced in surface horizons (e.g., root exudates) might accumulate due to drainage limitations imposed by the permafrost (Michaelson et al., 1998; Mikan et al., 2002; Michaelson and Ping, 2003). Alternatively, in some soil environments, cryochemical precipitation of dissolved organic carbon might result in the deposition of rather stable SOM near the permafrost table (Gundelwein et al., 2007).

Because so much SOM is currently stabilized simply by environmental conditions, most efforts to evaluate the quality of organic carbon stored in permafrost region soils have focused on characterizing the chemical composition of the organic matter (e.g., Dai et al., 2002a; Turetsky et al., 2007; Pedersen et al., 2011). Chemical characterization studies have run the gamut of methodologies in efforts to assess the current state of degradation - from wet chemical fractionations (acid/base extractions, molecular biomarkers, and water or solvent extractions; e.g., Uhlî̃ová et al., 2007; Paulter et al., 2010; Hugelius et al., 2012) to various types of spectrochemical analysis (nuclear magnetic resonance spectroscopy, pyrolysis-gas chromatography/mass spectrometry, mid-infrared spectroscopy; e.g., Dai et al., 2002a, b; Andersen and White, 2006; Waldrop et al., 2010; Pedersen et al., 2011; Pengerud et al., 2013). Even though organomineral associations might play a role in the relative persistence of SOM upon thawing and warming (Davidson and Janssens, 2006), relatively few studies have employed physical fractionations to characterize the amount of SOC stabilized by mineral associations or by aggregation (e.g., Dutta et al., 2006; Xu et al., 2009a, b; Höfle et al., 2013).

These varied techniques provide different perspectives of the composition of organic matter stored in permafrost soils and its potential resistance to decomposition. In general, wet chemical and physical fractionations enable estimates of pool sizes for SOM of different qualities, whereas spectrochemical analyses provide more specific information on SOM chemistry. From the perspective of the permafrost region as a whole, application of these methods to a range of soils and horizons provides similar overall conclusions for permafrost soils. In general, wet chemical and spectrochemical methods indicate that (1) the bulk of the organic matter in permafrostaffected soils is relatively less decomposed or "humified" than that of more temperate soils; (2) plant-derived materials are often more prevalent than microbial residues; and 
(3) environmental conditions have promoted the preservation of relatively labile SOM constituents (e.g., Ping et al., 1997; Dai et al., 2002a, b; Pedersen et al., 2011; Hugelius et al., 2012; Paulter et al., 2010). Physical fractionation approaches have provided comparable information. For example, Diochon et al. (2013) found that lightly decomposed particulate organic matter (POM) was a greater component (usually $>30 \%$ ) of the total SOC in active-layer and permafrost horizons of Canadian Turbic Cryosols than is typical for temperate soils. For similar horizons in two Alaskan Turbels, Xu et al. (2009a, b) reported even greater proportions of total SOC $(>70 \%)$ in the POM fractions, and analysis of this material by pyrolysis-gas chromatography/mass spectrometry indicated that it was only lightly decomposed. Moreover, Höfle et al. (2013) concluded that organomineral associations and aggregation are of lesser importance for SOM stabilization in permafrost soils than in temperate and tropical soils. Indeed, this is not surprising, because most clay minerals in Arctic tundra soils are inherent from the parent material rather than pedogenic (Borden et al., 2010). The lack of reactivity of these clay minerals was further demonstrated by the lack of correlation between clay content and cation exchange capacity (Ping et al., 2005b).

More direct assessments of the potential decomposability of SOM have been made by measuring SOC mineralization in laboratory incubation studies (e.g., Michaelson and Ping, 2003; Lee et al., 2012; Elberling et al., 2013; Knoblauch et al., 2013). To date, most incubation studies have been relatively short term (weeks to a few months) and thus are assessments of the most bioavailable components of SOM. Some studies have combined chemical or physical characterizations with incubations in an effort to relate SOM composition to decomposition rates or to identify indices of decomposability (e.g., White et al., 2002, 2004; Weintraub and Schimel, 2003; Waldrop et al., 2010; Diochon et al., 2013; Paré and Bedard-Haughn, 2013; Pengerud et al., 2013; Treat et al., 2014). In general, SOM of higher quality (less decomposed and rich in polysaccharides and proteins) is positively related to mineralization rates.

Long-term ( $>1$ year) incubation studies provide better assessments of the integrated effects of multiple SOM chemistries and stabilization mechanisms on mineralization rates and also can inform the estimates of turnover rate functions used in process models. But, to date, the number of studies of this length for permafrost soils has been quite limited (Schädel et al., 2014). Initial or short-term mineralization is often related to the amount of dissolved or waterextractable organic carbon. But for longer-term incubations, the mineralization observed in thawed permafrost soils has been related to total SOC concentration and to differences in SOM quality at the time of permafrost incorporation (Dutta et al., 2006; Lee et al., 2012; Knoblauch et al., 2013). In a synthesis of eight long-term aerobic incubation studies ( $>1$ year) including 121 samples from upland sites in 23 high-latitude ecosystems, Schädel et al. (2014) estimated
SOC pool sizes and turnover times from a three-pool decomposition model. They projected a 20-90 \% loss of initial SOC within 50 incubation years at $5^{\circ} \mathrm{C}$, with greater losses occurring for soils with higher carbon to nitrogen ratios. However, the importance of oxygen availability for mineralization rates was demonstrated by Elberling et al. (2013). At the end of their 12.5 year incubation study, only $9 \%$ of the initial organic carbon in a saturated upper permafrost soil from a wet grassland site was mineralized compared to $75 \%$ of initial carbon lost when the same soil was drained before incubation.

In addition to intrinsic soil differences (i.e., SOM quality and mineral composition) and incubation time, the outcome and conclusions drawn from incubation studies are highly dependent upon experimental conditions including sample handling/disturbance, temperature, moisture conditions, oxygen availability, and experimental additions of labile carbon substrates and nutrients. For example, Dai et al. (2002b) found that the most bioreactive compound was polysaccharides at $4{ }^{\circ} \mathrm{C}$, whereas at $25^{\circ} \mathrm{C}$, more resistant fractions such as lignin were consumed. Such shifts in substrate utilization at higher temperatures might reflect changes in the active microbial community that may not be realistic under most field conditions. In another case, Wild et al. (2014) showed that the mineralization rates of surface organic soil, mineral subsoil, and cyroturbated organic material in the subsoil (all from the active layer) were each differentially limited by the availability of labile organic carbon substrates or nitrogen. Importantly, however, many of the conditions impacting mineralization rates in incubation studies are indicative of factors responsible for variations in overall SOC storage, turnover times, and the intrinsic relative degradation state of SOM on subregion, landscape, and local scales (e.g., Kaiser et al., 2007; Hugelius et al., 2012; Paré and Bedard-Haughn, 2013; Pengerud et al., 2013)

\section{Role and future of permafrost soils in climatic change}

Climatic change at high latitudes is causing region-wide warming, hydrologic changes, and other related disturbances (e.g., fires) that are triggering widespread degradation and thawing of permafrost with potential global impacts (Jorgenson et al., 2010; Romanovsky et al., 2010; Rowland et al., 2010). One of the most likely and important consequences of sustained warming in circumpolar regions is the thawing of permafrost soils and the subsequent release of carbon as carbon dioxide and methane to the atmosphere due to enhanced microbial mineralization of previously frozen SOC stocks (Oechel et al., 1993; Zimov et al., 1993; Goulden and Crill, 1997; Melillo et al., 2002; Eliasson et al., 2005; Zhuang et al., 2007; Schuur et al., 2009, 2011).

Model simulations of carbon losses from thawing permafrost are highly uncertain and vary widely - with predic- 
tions of cumulative net transfers to the atmosphere ranging from 7 to $250 \mathrm{Pg} \mathrm{C}$ by 2100,121 to $302 \mathrm{PgC}$ by 2200 , and 180 to $380 \mathrm{Pg} \mathrm{C}$ by 2300 for intermediate to high fossil fuel emission scenarios (Zhuang et al., 2006; Koven et al., 2011; Schaefer et al., 2011; Burke et al., 2012; MacDougall et al., 2012; Schneider von Deimling et al., 2012). Such large releases of greenhouse gases are expected to have a positive feedback to Earth's atmosphere, leading to further warming (Schuur et al., 2008, 2011; Schaefer et al., 2011; Burke et al., 2012; MacDougall et al., 2012; Schneider von Deimling et al., 2012). But, there are large uncertainties in model predictions of carbon-climate feedbacks caused by warming of northern circumpolar regions (Koven et al., 2011; Burke et al., 2012). Furthermore, a discrepancy exists between the baseline SOC stock estimates generated by Earth system models and observation-based estimates of SOC stocks for the permafrost region (Mishra et al., 2013). Resolving these issues will require improved empirical estimates as well as better model representations of the unique processes controlling the formation and stabilization of SOC stocks in permafrost regions (Mishra et al., 2013; Zubrzycki et al., 2014).

In addition to the uncertainties surrounding current estimates of SOC stocks, even less is known about the potential vulnerability of organic carbon stored in permafrost soils to climatic change, and how this varies across land-cover classes or soil types within different eco-regions (Schuur et al., 2008; Kuhry et al., 2010, 2013). Upon thawing, the initial intrinsic degradation state of previously frozen SOC pools depends on the type of permafrost formation, the origin and chemistry of the SOM, and the extent of mineralization and transformation that occurred before these materials were incorporated into permafrost (Hobbie et al., 2000; Kuhry et al., 2009; Hugelius et al., 2012; Knoblauch et al., 2013). Often, SOM stored in permafrost has undergone some level of decay before its incorporation in perennially frozen horizons (Pedersen et al., 2011; Hugelius et al., 2012). This may be particularly true for SOM stabilized in epigenetic permafrost deposits (permafrost formed after deposition of soil material) (Schuur et al., 2008). But, in cryoturbated soils or syngenetic permafrost deposits (permafrost formed more or less concurrently with deposition of soil material, such as Yedoma or some peat deposits), relatively undecomposed organic materials were sometimes rapidly buried and frozen (Zimov et al., 2006; Sannel and Kuhry, 2009). Even in epigenetic permafrost, the extent of SOM degradation can be limited if anoxia or other factors constrained decomposition before permafrost formation (Hugelius et al., 2012).

Thus, there is a need to develop biogeochemical indicators that reflect differences in the genesis and past history of SOM before incorporation into permafrost and that represent its intrinsic relative degradation state (Kuhry et al., 2010; Hugelius et al., 2012). With such indicators, maps of the spatial and vertical distributions of SOC stocks could be coupled with an indication of the potential decomposability of these carbon stocks. At the same time, additional targeted mecha- nistic and process-based investigations are needed to better understand the complex interactions and feedbacks among SOM, vegetation, decomposers, nutrients, and hydrology induced by climatic changes. Taken together, this information would substantially improve observationally based predictions of the impacts of soil warming and permafrost thawing on SOC stocks and their future dynamics as well as contribute significantly to the parameterization, calibration, and validation of regional and Earth system models (Schuur et al., 2008; Burke et al., 2012; Hugelius et al., 2012; Mishra et al., 2013; Zubrzycki et al., 2014).

\section{Conclusions}

Soils in the permafrost regions have received considerable recent attention because of their disproportionally high carbon stocks in comparison to soils of non-permafrost regions and because of the attendant implications for global climate change. One of the most likely and important consequences of sustained warming in circumpolar regions is the thawing of permafrost coupled with subsequent effects on soil hydrology and resulting transformations of the permafrost landscape. Increased paludification is expected due to increased thermokarsting on the coastal plains and lowlands and due to the shifting of water, carbon and nutrients from uplands to basins or valleys. In addition to elevated fluxes of carbon dioxide and methane to the atmosphere, there will be a shifting of the proportional releases of these two gases, with increased methane emissions likely occurring in areas where the spatial extent of wetland soils increase. These changes can be evaluated through landform modeling based on newly developed remote sensing technologies such as high-resolution lidar. Meanwhile, the vulnerability of organic carbon stocks in permafrost soils to changing climatic conditions will depend on the interactions of SOM composition with numerous other controlling factors that also are likely to respond to climatic changes (such as temperature, hydrology, nutrient availability, new carbon inputs from changing plant communities, and changing associations with soil minerals). These interactions will affect the integrated activities of the microbial community, as well as the physical access of decomposers and their enzymes to thawed carbon pools. All of these factors and interactions can only be assessed through a combination of laboratory studies, integrated observational and manipulative field studies, geospatial upscaling and mapping of SOC stocks and indicators of their decomposability, as well as ecosystem, regional, and Earth system modeling studies. 
Acknowledgements. This material is based upon work supported by the US Department of Agriculture NIFA Hatch funds and by the Alaska State Soil Classification project (CLP and GJM), and by the US Department of Energy, Office of Science, Office of Biological and Environmental Research under contract no. DE-AC02-06CH11357 (JDJ).

Edited by: D. Weindorf

\section{References}

Ahrens, R. J., Bockheim, J. G., and Ping, C. L.: The Gelisol order in Soil Taxonomy, in: Cryosols - Permafrost-Affected Soils, edited by: Kimble, J. M., Springer-Verlag, Berlin, 627-635, 2004.

Amacher, M. C., Henderson, R. E., Brupbachera, R. H., and Sedberry Jr., J. E.: Dichromate-oxidizable and total organic carbon contents of representative soils of the major soil areas of Louisiana, Comm. Soil Sci. and Plant Anal., 17, 1019-1032, 1986.

Amundson, R.: The carbon budget in soils, Annu. Rev. Earth Planet. Sci., 29, 535-562, 2001.

Andersen, S. K. and White, D. M.: Determining soil organic matter quality under anaerobic conditions in arctic and subarctic soils, Cold Reg. Sci. Technol., 44, 149-158, 2006.

Atjay, G. L., Ketner, P., and Duvigneaud, P.: Terrestrial primary production and phytomass, in: The Global Carbon Cycle, edited by: Bolin, B., Degens, E. T., Kempe, S., and Ketner, P., SCOPE, 13, Wiley, Chichester, UK, 129-182, 1979.

Baldock, J. A. and Skjemstad, J. O.: Role of the soil matrix and minerals in protecting natural organic materials against biological attack, Org. Geochem., 31, 697-710, 2000.

Beyer, L., Sorge, C., Blume, H.-P., and Schulten, H.-R.: Soil organic matter composition and transformation in gelic Histosols of coastal continental Antarctica, Soil Biol. Biochem., 27, 12791288,1995

Beyer, L., Bockheim, J. G., Campbell, I. B., and Claridge, G. G. C.: Genesis, properties and sensitivity of Antarctic Gelisols, Antarct. Sci., 11, 387-398, 1999.

Beyer, L., Pingpank, K., Wriedt, G., and Bölter, M.: Soil formation in coastal continental Antarctica (Wilkes Land), Geoderma, 95, 283-304, 2000.

Bliss, N. B. and Maursetter, J.: Soil organic carbon stocks in Alaska estimated with spatial and pedon data, Soil Sci. Soc. Am. J., 74, 565-579, 2010.

Blume, H. P., Beyer, L., Bölter, M., Erlenkeuser, H., Kalk, E., Kneesch, S., and Schneider, D.: Pedogenic zonation in soils of the Southern Circum-Polar Region, Adv. GeoEcol., 30, 69-90, 1997.

Bockheim, J. G.: Soil development rates in the Transantarctic Mountains, Geoderma, 47, 59-77, 1990.

Bockheim, J. G.: Permafrost distribution in the southern circumpolar region and its relation to the environment: a review and recommendations for further research, Permafrost Periglac., 6, 27-45, 1995.

Bockheim, J. G. and Hinkel, K. M.: The importance of "deep" organic carbon in permafrost-affected soils of arctic Alaska, Soil Sci. Soc. Am. J., 71, 1889-1892, 2007.
Bockheim, J. G. and Tarnocai, C.: Recognition of cryoturbation for classifying permafrost-affected soils, Geoderma, 81, 281-293, 1998.

Bockheim, J. G., Walker, D. A., Everett, L. R., Nelson, F. E., and Shiklomanov, N. I.: Soils and cryoturbation in moist nonacidic and acidic tundra in the Kuparuk River Basin, arctic Alaska, U.S.A., Arctic Alpine Res., 30, 166-174, 1998.

Bockheim, J. G., Everett, L. R., Hinkel, K. M., Nelson, F. E., and Brown, J.: Soil organic carbon storage and distribution in arctic tundra, Barrow, Alaska, Soil Sci. Soc. Am. J., 63, 934-940, 1999.

Bohn, H. L.: Estimate of organic carbon in world soils: II, Soil Sci. Soc. Am. J., 46, 1118-1119, 1982.

Boike, J., Kattenstroth, B., Abramova, K., Bornemann, N., Chetverova, A., Fedorova, I., Fröb, K., Grigoriev, M., Grüber, M., Kutzbach, L., Langer, M., Minke, M., Muster, S., Piel, K., Pfeiffer, E.-M., Stoof, G., Westermann, S., Wischnewski, K., Wille, C., and Hubberten, H.-W.: Baseline characteristics of climate, permafrost and land cover from a new permafrost observatory in the Lena River Delta, Siberia (1998-2011), Biogeosciences, 10, 2105-2128, doi:10.5194/bg-10-2105-2013, 2013.

Borden, P. W., Ping, C. L., McCarthy, P. J., and Naidu, S.: Clay mineralogy in arctic tundra Gelisols, northern Alaska, Soil Sci. Soc. Am. J., 74, 580-592, 2010.

Brink, V. C., Pearce, D. G., Mackay, J. R., and Freyman, S.: Needle ice and seedling establishment in southwestern British Columbia, Can. J. Plant Sci., 47, 135-139, 1967.

Broll, G. and Tarnocai, C.: Turf hummocks on Ellesmere Island, Canada, in: Transactions of the 17th World Congress of Soil Science, 2002.

Brown, J.: Radiocarbon dating, Barrow, Alaska, Arctic, 18, 36-48, 1965.

Brown, J.: Soil properties developed on the complex tundra relief of northern Alaska, Biuletyn Perygacjalny, 18, 153-167, 1969.

Brown, J. and Kreig, R. A. (Eds.): Guidebook to Permafrost and Related Features Along the Elliott and Dalton Highways, Fox to Prudhoe Bay, Alaska, Alaska Division of Geological and Geophysical Surveys, Department of Natural Resources, Fairbanks, Alaska, 1983.

Brown, J., Ferrians Jr., O. J., Heginbottom, J. A., and Melnikov, E. S.: Circum-Arctic Map of Permafrost and Ground Ice Conditions, National Snow and Ice Data Center, Boulder, Colorado, Digital media 1998, revised February, 2001.

Burke, E. J., Hartley, I. P., and Jones, C. D.: Uncertainties in the global temperature change caused by carbon release from permafrost thawing, The Cryosphere, 6, 1063-1076, doi:10.5194/tc6-1063-2012, 2012.

Burn, C. R.: The active layer: two contrasting definitions, Permafrost Periglac., 9, 411-416, 1998.

Burn, C. R. and Smith, M. W.: Development of thermokarst lakes during the Holocene at sites near Mayo, Yukon Territory, Permafrost Periglac., 1, 161-175, 1990.

Campbell, I. B. and Claridge, G. G. C.: Cryosols of the arid Antarctic, in: Cryosols - Permafrost-Affected Soils, edited by: Kimble, J. M., Springer-Verlag, Berlin, 291-302, 2004a.

Campbell, I. B. and Claridge, G. G. C.: Soil properties and relationships in Cryosols of the region of the Transantarctic Mountains in Antarctica, in: Cryosols - Permafrost-Affected Soils, edited by: Kimble, J. M., Springer-Verlag, Berlin, 713-726, 2004 b. 
Campbell, I. B., Claridge, G. G. C., Campbell, D. I., and Balks, M. R.: Permafrost properties in the McMurdo Sound-Dry Valley region of Antarctica, in: Proceedings of Seventh International Conference on Permafrost, Yellowknife, Canada, edited by: Lewkowicz, A. G. and Allard, M., Universite Laval, Centre d'études nordiques, Collection Nordicana, No.57, 121-126, 1998.

Claridge, G. G. C. and Campbell, I. B.: The biology of arid Cryosols, in: Cryosols - Permafrost-Affected Soils, edited by: Kimble, J. M., Springer-Verlag, Berlin, 573-580, 2004.

Czudek, T. and Demek, J.: Thermokarst in Siberia and its influence on the development of lowland relief, Quaternary Res., 1, 103120, 1970.

Dai, X. Y., Ping, C. L., and Michaelson, G. J.: Characterization of soil organic matter in Arctic tundra soils by different analytical approaches, Organic Geochem., 33, 407-419, 2002 a.

Dai, X. Y., White, D., and Ping, C. L.: Evaluation of soil organic matter composition and bioavailability by pyrolysis-gas chromatography/mass spectrometry, J. Anal. Appl. Pyrol., 62, 249258, 2002b.

Davidson, E. A. and Janssens, I. A.: Temperature sensitivity of soil carbon decomposition and feedbacks to climate change, Nature, 440, 165-173, 2006.

Davis, N.: Permafrost - A Guide to Frozen Ground in Transition, University of Alaska Press, Fairbanks, Alaska, 351 pp., 2001.

Desyatkin, R. V.: Soil Formation in Thermokarst Depressions (Alases) of the Permafrost Zone, Nauka, Novosibirsk, Russia, 323 pp., 2008 (in Russian).

Diochon, A., Gregorich, E. G., and Tarnocai, C.: Evaluating the quantity and biodegradability of soil organic matter in some Canadian Turbic Cryosols, Geoderma, 202-203, 82-87, 2013.

Dutta, K., Schuur, E. A. G., Neff, J. C., and Zimov, S. A.: Potential carbon release from permafrost soils of Northeastern Siberia, Glob. Change Biol., 12, 2336-2351, 2006.

Dyke, A. S. and Zoltai, S. C.: Radiocarbon-dated mudboils, central Canadian Arctic, Current Research, Part B, Geological Survey of Canada, Paper 80-1B, 271-275, 1980.

Elberling, B., Michelsen, A., Schädel, C., Schuur, E. A. G., Christiansen, H. H., Berg, L., Tamstorf, M. P., and Sigsgaard, C.: Long-term $\mathrm{CO}_{2}$ production following permafrost thaw, Nat. Clim. Change, 3, 890-894, 2013.

Eliasson, P. E., McMurtrie, R. E., Pepper, D. A., Stromgren, M., Linder, S., and Agren, G. I.: The response of heterotrophic $\mathrm{CO}_{2}$ flux to soil warming, Glob. Change Biol., 11, 167-181, 2005.

Eswaran, H., Van Den Berg, E., and Reich, P.: Organic carbon in soils of the world, Soil Sci. Soc. Am. J., 57, 192-194, 1993.

Everett, K. R. and Brown, J.: Some recent trends in the physical and chemical characterization and mapping of tundra soils, arctic slope of Alaska, Soil Sci., 133, 264-280, 1982.

Everett, K. R., Vassiljevskaya, V. P., Brown, J., and Walker, B. D.: Tundra and analogous soils, in: Tundra Ecosystems: a Comparative Analysis, edited by: Bliss, L. C., Heal, O. W., and Moore, J. J., Cambridge University Press, Cambridge, UK, 139-179, 1981.

Fahnestock, J. T., Jones, M. H., and Welker, J. M.: Wintertime $\mathrm{CO}_{2}$ efflux from arctic soils: Implications for annual carbon budgets, Global Biogeochem. Cy., 13, 775-779, 1999.

Frank-Fahle, B. A., Yergeau, É., Greer, C. W., Lantuit, H., and Wagner, D.: Microbial functional potential and community composition in permafrost-affected soils of the NW Canadian Arc- tic, PLoS ONE, 9, e84761, doi:10.1371/journal.pone.0084761, 2014.

French, H. M.: Active layer processes, in: Advances in Periglacial Geomorphology: New York, John Wiley and Sons, 151-177, 1988.

French, H. M.: The Periglacial Environment, 3rd Edn., John Wiley \& Sons, 2007.

French, H. M. and Shur, Y.: The principles of cryostratigraphy, Earth Sci. Rev., 101, 190-206, doi:10.1016/j.earscirev.2010.04.002, 2010.

Froese, D. G., Westgate, J. A., Reyes, A. V., Enkin, R. J., and Preece, S. J.: Ancient permafrost and a future warmer Arctic, Science, 321, p. 1648, doi:10.1126/science.1157525, 2008.

Geisler, E. and Ping, C. L.: Effects of periglacial processes on soil formation in subarctic Alaska, ASA, CSSA, SSSA International Annual Meetings, Tampa, FL, 3-6 November 2013, Abstract no. 126-3, 2013.

Gilichinsky, D., Abakumov, E., Abramov, A., Fyodorov-Davydov, D., Goryachkin, S., Lupachev, A., Mergelov, M., and Zazovskaya, E.: Soils of mid and low Antarctic: diversity, geography, temperature regime, in: Proceedings 19th World Congress of Soil Science, Soil Solutions for a Changing World, Brisbane, Australia, 1-6 August 2010, edited by: Gilkes, R. J. and Prakonkep, N., Working Group 1.4 Cold Soil in a changing world, 32-35, 2010.

Gilichinsky, D. A. and Rivkina, E. M.: Permafrost microbiology, in: Encyclopedia of Geobiology, edited by: Reitner, J. and Thiel, V., Springer, Netherlands, 726-732, 2011.

Godin, E., Fortier, D., and Coulombe, S.: Effects of thermoerosion gullying on hydrologic flow networks, discharge and soil loss, Environ. Res. Lett., 9, 105010, doi:10.1088/17489326/9/10/105010, 2014.

Gong, Z. T.: Chinese Soil Taxonomy. Science Press, Beijing, 2001.

Goulden, M. L. and Crill, P. M.: Automated measurements of $\mathrm{CO}_{2}$ exchange at the moss surface of a black spruce forest, Tree Physiol., 17, 537-542, 1997.

Gracheva, R. G.: Cryosols of the mountains of Southern Siberia and far Eastern Russia, in: Cryosols - Permafrost-Affected Soils, edited by: Kimble, J. M., Springer-Verlag, Berlin, 231-252, 2004.

Grosse, G., Harden, J., Turetsky, M., McGuire, A. D., Camill, P., Tarnocai, C., Frolking, S., Schuur, E. A. G., Jorgenson, T., Marchenko, S., Romanovsky, V., Wickland, K. P., French, N., Waldrop, M., Bourgeau-Chavez, L., and Striegl, R. G.: Vulnerability of high-latitude soil organic carbon in the North America to disturbance, J. Geophy. Res., 116, G00K06, doi:10.1029/2010JG001507, 2011.

Grosse G., Jones, B., and Arp, C.: Thermokarst lakes, drainage, and drained basins, in: Treatise on Geomorphology, Vol. 8, Glacial and Periglacial Geomorphology, edited by: Shroder, J. F. (Ed.-inchief), Giardino, R., and Harbor, J. (Vol. Eds), Academic Press, San Diego, 325-353, 2013.

Gubin, S. V.: Late Pleistocene soil formation on coastal lowlands of northern Yakutia, Pochvovedeniye, 10, 62-70, 1993 (in Russian).

Gubin, S. V. and Lupachev, A. V.: Soil formation and the underlying permafrost, Eurasian Soil Sci., 41, 574-585, 2008.

Gundelwein, A., Müller-Lupp, T., Sommerkorn, M., Haupt, E. T. K., Pfeiffer, E.-M., and Wiechmann, H.: Carbon in tundra soils 
in the Lake Labaz region of arctic Siberia, Eur. J. Soil Sci., 58, 1164-1174, 2007.

Hallet, B. and Prestrud, S.: Dynamics of periglacial sorted circles in Western Spitsbergen, Quaternary Res., 26, 81-99, 1986.

Harden, J. W., Koven, C. D., Ping, C. L., Hugelius, G., McGuire, A. D., Camill, P., Jorgenson, T., Kuhry, P., Michaelson, G. J., O'Donnell, J. A., Schuur, E. A. G., Tarnocai, C., Johnson, K., and Grosse, G.: Field information links permafrost carbon to physical vulnerabilities of thawing, Geophy. Res. Lett., 39, L15704, doi:10.1029/2012GL051958, 2012.

Hinkel, K. M., Eisner, W. E., Bockheim, J. G., Nelson, F. E., Peterson, K. M., and Dai, X. Y.: Spatial extent, age, and carbon stocks in drained thaw lake basins on the Barrow Peninsula, Arct. Antarct. Alp. Res., 35, 291-300, 2003.

Hinkel, K. M., Frohn, R. C., Nelson, F. E., Eisner, W. R., and Beck, R. A.: Morphometric and spatial analysis of thaw lakes and drained thaw lake basins in the western Arctic Coastal Plain, Alaska, Permafrost Periglac., 16, 327-341, 2005.

Hobbie, S. E., Schimel, J. P., Trumbore, S. E., and Randerson, J. R.: Controls over carbon storage and turnover in high-latitude soils. Glob. Change Biol., 6 (Suppl.1), 196-210, 2000.

Höfle, C. and Ping, C. L.: Properties and soil development of latePleistocene paleosols from Seward Peninsula, northwest Alaska, Geoderma, 71, 219-243, 1996.

Höfle, S., Rethemeyer, J., Mueller, C. W., and John, S.: Organic matter composition and stabilization in a polygonal tundra soil of the Lena Delta, Biogeosciences, 10, 3145-3158, doi:10.5194/bg10-3145-2013, 2013.

Horwath, J. L., Sletten, R. S., Hagedon, B., and Hallet, B.: Spatial and temporal distribution of soil organic carbon in nonsorted striped patterned ground of the High Arctic, J. Geophy. Res., 113, G03S07, doi:10.1029/2007JG000511, 2008.

Hugelius, G.: Spatial upscaling using thematic maps: An analysis of uncertainties in permafrost soil carbon estimates, Global Biogeochem. Cy., 26, GB2026, doi:10.1029/2011gb004154, 2012.

Hugelius, G. and Kuhry, P.: Landscape partitioning and environmental gradient analyses of soil organic carbon in a permafrost environment, Global Biogeochem. Cy., 23, GB3006, doi:10.1029/2008gb003419, 2009.

Hugelius, G., Kuhry, P., Tarnocai, C., and Virtanen, T.: Soil organic carbon pools in a periglacial landscape: a case study from the central Canadian Arctic, Permafrost Periglac., 21, 16-29, 2010.

Hugelius, G., Virtanen, T., Kaverin, D., Pastukhov, A., Rivkin, F., Marchenko, S., Romanovsky, V., and Kuhry, P.: Highresolution mapping of ecosystem carbon storage and potential effects of permafrost thaw in periglacial terrain, European Russian Arctic, J. Geophy. Res.-Biogeosci., 116, G03024, doi:10.1029/2010jg001606, 2011.

Hugelius, G., Routh, J., Kuhry, P., and Crill, P.: Mapping the degree of decomposition and thaw remobilization potential of soil organic matter in discontinuous permafrost terrain, J. Geophys. Res., 117, G02030, doi:10.1029/2011JG001873, 2012.

Hugelius, G., Bockheim, J. G., Camill, P., Elberling, B., Grosse, G., Harden, J. W., Johnson, K., Jorgenson, T., Koven, C. D., Kuhry, P., Michaelson, G., Mishra, U., Palmtag, J., Ping, C.-L., O’Donnell, J., Schirrmeister, L., Schuur, E. A. G., Sheng, Y., Smith, L. C., Strauss, J., and Yu, Z.: A new data set for estimating organic carbon storage to $3 \mathrm{~m}$ depth in soils of the northern cir- cumpolar permafrost region, Earth Syst. Sci. Data, 5, 393-402, doi:10.5194/essd-5-393-2013, 2013a.

Hugelius, G., Tarnocai, C., Broll, G., Canadell, J. G., Kuhry, P., and Swanson, D. K.: The Northern Circumpolar Soil Carbon Database: spatially distributed datasets of soil coverage and soil carbon storage in the northern permafrost regions, Earth Syst. Sci. Data, 5, 3-13, doi:10.5194/essd-5-3-2013, 2013 b.

Hugelius, G., Strauss, J., Zubrzycki, S., Harden, J. W., Schuur, E. A. G., Ping, C. L., Schirrmeister, L., Grosse, G., Michaelson, G. J., Koven, C. D., O’Donnell, J. A., Elberling, B., Mishra, U., Camill, P., Yu, Z., Palmtag, J., and Kuhry, P.: Estimated stocks of circumpolar permafrost carbon with quantified uncertainty ranges and identified data gaps, Biogeosciences, 11, 6573-6593, doi:10.5194/bg-11-6573-2014, 2014.

IUSS Working Group WRB: World Reference Base for Soil Resources 2014, International Soil Classification System for Naming Soils and Creating Legends for Soil Maps, World Soil Resources Reports No. 106, FAO, Rome, 2014.

Jastrow, J. D., Amonette, J. E., and Bailey, V. L.: Mechanisms controlling soil carbon turnover and their potential application for enhancing carbon sequestration, Climatic Change, 80, 5-13, 2007.

Jensen, A. E., Lohse, K. A., Crosby, B. T., and Mora, C. I.: Variations in soil carbon dioxide efflux across a thaw slump chronosequence in northwestern Alaska. Environ. Res. Lett., 9, 025001 doi:10.1088/1748-9326/9/2/025001, 2014.

Jobbágy, E. G. and Jackson, R. B.: The vertical distribution of soil organic carbon and its relation to climate and vegetation, Ecol. Appl., 10, 423-436, 2000.

Johnson, K. D., Harden, J., McGuire, A. D., Bliss, N. B., Bockheim, J. G., Clark, M., Nettleton-Hollingsworth, T., Jorgenson, M. T., Kane, E. S., Mack, M., O’Donnell, J., Ping, C. L., Schuur, E. A. G., Turetsky, M. R., and Valentine, D. W.: Soil carbon distribution in Alaska in relation to soil-forming factors, Geoderma, 167-168, 71-84, 2011.

Jones, A., Stolbovoy, V., Tarnocai, C., Broll, G., Spaargaren, O., and Montanarella, L.: Soil Atlas of the Northern Circumpolar Region, European Commission, Publications Office of the European Union, Luxemborg, 144 pp., 2010.

Jorgenson, M. T.: Thermokarst terrains, in: Treatise on Geomorphology, Vol 8, Glacial and Periglacial Geomorphology, edited by: Shroder, J.F. (Ed.-in-chief), Giardino, R. and Harbor, J. (Vol. Eds), Academic Press, San Diego, 313-324, 2013.

Jorgenson, M. T. and Shur, Y.: Evolution of lakes and basins in northern Alaska and discussion of the thaw lake cycle, J. Geophy. Res., 112 F02S17, doi:10.1029/2006JF000531, 2007.

Jorgenson, M. T., Roth, J. E., Anderson, B. A., Smith, M. D., Lawhead, B. E., and Schlentner, S. F.: Ecological Land Evaluation for the Yukon Training Area on Fort Wainwright, Alaska: Permafrost, Disturbance, and Habitat Use, U.S. Army Cold Regions Research and Engineering Laboratory, Hanover, NH, 88 pp., 2000.

Jorgenson, M. T., Shur, Y. L., and Pullman, E. R.: Abrupt increase in permafrost degradation in Arctic Alaska, Geophys. Res. Lett., 33, L02503, doi:10.1029/2005GL024960, 2006.

Jorgenson, M. T., Romanovsky, V., Harden, J., Shur, Y., O’Donnell, J., Schuur, E. A. G., Kanevskiy, M., and Marchenko, S.: Resilience and vulnerability of permafrost to climate change, Can. J. Forest Res., 40, 1219-1236, 2010. 
Jorgenson, M. T., Harden, J., Kanevskiy, M., O’Donnell, J., Wickland, K., Ewing, S., Manies, K., Zhuang, Q., Shur, Y., Striegl, R., and Koch, J.: Reorganization of vegetation, hydrology and soil carbon after permafrost degradation across heterogeneous boreal landscapes, Environ. Res. Lett., 8, 035017, doi:10.1088/17489326/8/3/035017, 2013.

Kade, A. and Walker, D. A.: Experimental alteration of vegetation on nonsorted circles: Effects on cryogenic activity and implications for climate change in the Arctic, Arct. Antarct. Alp. Res., 40, 96-103, doi:10.1657/1523-0430(06-029)[KADE]2.0.CO;2, 2008.

Kaiser, C., Meyer, H., Biasi, C., Rusalimova, O., Barsukov, P., and Richter, A.: Storage and mineralization of carbon and nitrogen in soils of a frost-boil tundra ecosystem in Siberia, J. Appl. Soil Ecol., 29, 173-183, 2005.

Kaiser, C., Meyer, H., Biasi, C., Rusalimova, O., Barsukov, P., and Richter, A.: Conservation of soil organic matter through cryoturbation in arctic soils in Siberia, J. Geophy. Res., 112, G02017, doi:10.1029/2006JG000258, 2007.

Kanevskiy, M., Shur, Y., Fortier, D., Jorgenson, M. T., and Stephani, E.: Cryostratigraphy of late Pleistocene syngenetic permafrost (yedoma) in northern Alaska, Itkillik River exposure, Quaternary Res., 75, 584-596, doi:10.1016/j.yqres.2010.12.003, 2011.

Kanevskiy, M., Shur, Y., Jorgenson, M. T., Ping, C. L., Michaelson, G. J., Fortier, D., Stephani, E., Dillon, T., and Tumskoy, V.: Ground ice of the upper permafrost of the Beaufort Sea coast of Alaska, Cold Reg. Sci. Technol., 85, 56-70, doi:10.1016/j.coldregions.2012.08.002, 2013.

Kanevskiy, M., Jorgenson, T., Shur, Y., O’Donnell, J. A., Harden, J. W., Zhuang, Q., and Fortier, D.: Cryostratigraphy and permafrost evolution in the lacustrine lowlands of West-Central Alaska, Permafrost Periglac., 25, 14-34, 2014.

Karavaeva, N. A.: Tundra Soils of Northern Yakutia, Nauka, Moscow, 1969 (in Russian).

Kelleher, B. P. and Simpson, A. J.: Humic substances in soils: Are they really chemically distinct?, Environ. Sci. Technol., 40, 4605-4611, 2006.

Kessler, M. A., Murray, A. B., Werner, B. T., and Hallet, B.: A model for sorted circles as self-organized patterns, J. Geophy. Res., 106, 13287-13306, 2001.

Kimble, J. M., Tarnocai, C., Ping, C. L., Ahrens, R., Smith, C. A. S., Moore, J. P., and Lynn, W.: Determination of the amount of carbon in highly cryoturbated soils, in: Proceedings Joint Russian-American Seminar on Cryopedology and Global Change, Pushchino, Russia, 15-16 November 1992, edited by: Gilichinsky, D., Russian Academy of Sciences, Moscow, 277291, 1993.

Kleber, M.: What is recalcitrant soil organic matter?, Environ. Chem., 7, 320-332, 2010.

Kleber, M. and Johnson, M. G.: Advances in understanding the molecular structure of soil organic matter: Implications for interactions in the environment, Adv. Agron., 106, 77-142, 2010.

Knoblauch, C., Beer, C., Sosnin, A.,Wagner, D., and Pfeiffer, E.-M.: Predicting long-term carbon mineralization and trace gas production from thawing permafrost of Northeast Siberia, Glob. Change Biol., 19, 1160-1172, 2013.

Köchy, M., Hiederer, R., and Freibauer, A.: Global distribution of soil organic carbon, based on the Harmonized World Soil Database - Part 1: Masses and frequency distribution of SOC stocks for the tropics, permafrost regions, wetlands, and the world, SOIL Discuss., 1, 327-362, 2014.

Kokelj, S. V. and Jorgenson, M. T.: Advances in thermokarst research, Permafrost Periglac., 24, 108-119, 2013.

Konishchev, V. N.: Characteristics of cryogenic weathering in the permafrost zone of the European USSR, Arc. Alp. Res., 14, 261265, 1982.

Koven, C. D., Ringeval, B., Friedlingstein, P., Ciais, P., Cadule, P., Khvorostyanov, D., Krinner, G., and Tarnocai, C.: Permafrost carbon-climate feedbacks accelerate global warming, Proc. Natl. Acad. Sci. USA, 108, 14769-14774, 2011.

Kuhry, P., Mazhitova, G. G., Forest, P.-A., Deneva, S. V., Virtanen, T., and Kultti, S.: Upscaling soil organic carbon estimates for the Usa Basin (Northeast European Russia) using GIS-based landcover and soil classification schemes, Danish Journal of Geography, 102, 11-25, 2002.

Kuhry, P., Ping, C. L., Schuur, E. A. G., Tarnocai, C., and Zimov, S.: Report from the International Permafrost Association: Carbon pools in permafrost regions, Permafrost Periglac., 20, 229-234, 2009.

Kuhry, P., Dorrepaal, E., Hugelius, G., Schuur, E. A. G., and Tarnocai, C.: Potential remobilization of belowground permafrost carbon under future global warming, Permafrost Periglac., 21, 208-214, 2010.

Kuhry, P., Grosse, G., Harden, J. W., Hugelius, G., Koven, C. D., Ping, C. L., Schirrmeister, L., and Tarnocai, C.: Characterisation of the permafrost carbon pool, Permafrost Periglac., 24, 146155, 2013.

Lachenbruch, A. H.: Contraction theory of ice-wedge polygons: A qualitative discussion, in: Permafrost: International Conference Proceedings, Lafayette, IN, 11-15 November 1963, National Academy of Sciences - National Research Council, Washington, DC, Publication No. 1287, 63-71, 1966.

Landi, A., Mermut, A. R., and Anderson, D. W.: Carbon distribution in a hummocky landscape from Saskatchewan, Canada, Soil Sci. Soc. Am. J., 68, 175-184, 2004.

Lee, H., Schuur, E. A. G., Inglett, K. S., Lavoie, M., and Chanton, J. P.: The rate of permafrost carbon release under aerobic and anaerobic conditions and its potential effects on climate, Glob. Change Biol., 18, 515-527, 2012.

Lehmann, J., Solomon, D., Kinyangi, J., Dathe, L., Wirick, S., and Jacobsen, C.: Spatial complexity of soil organic matter forms at nanometer scales, Nat. Geosci., 1, 238-242, 2008.

Lewkowicz, A. G.: Slope hummock development, Fosheim Peninsula, Ellesmere Island, Nunavut, Canada, Quaternary Res., 75, 334-346, 2011.

Li, X., Cheng, G. D., Jin, H. J., Kang, E. S, Che, T., Jin, R., Wu, L. Z., Nan, Z. T., Wang, J., and Shen, Y. P.: Cryospheric change in China, Global Planet. Change, 62, 210-218, 2008.

Lipson, D. A., Jha, M., Raab, T. K., and Oechel, W. C.: Reduction of iron (III) and humic substances plays a major role in anaerobic respiration in an Arctic peat soil, J. Geophy. Res.-Biogeo., 115, G00I06, doi:10.1029/2009JG001147, 2010.

Lipson, D. A., Haggerty, J. M., Srinivas, A., Raab, T. K., Sathe, S., and Dinsdale, E. A.: Metagenomic insights into anaerobic metabolism along an Arctic peat soil profile. PLoS ONE, 8, e64659, doi:10.1371/journal.pone.0064659, 2013. 
MacDougall, A. H., Avis, C. A., and Weaver, A. J.: Significant existing commitment to warming from the permafrost carbon feedback, Nat. Geosci., 5, 719-721, 2012.

Mackay, J. R.: Reticulate ice veins in permafrost, Northern Canada, Can. Geotech. J., 11, 230-237, 1974.

Mackay, J. R.: The origin of hummocks, western Arctic coast, Canada, Can. J. Earth Sci., 17, 996-1006, 1980.

Makeev, O. V.: Facies of soil cryogenesis and associated soil profile features, Nauka, Moscow, 87 pp., 1981 (in Russian).

Makeev, O. W. and Kerzhentsev, A. S.: Cryogenic processes in the soils of northern Asia, Geoderma, 12, 101-109, 1974.

Marr, J. W.: Cyclical change in a patterned-ground ecosystem, Thile, Greenland, in: The Periglacial Environment, edited by: Péwé, T. L., McGill-Queen's University Press, Montreal, 177201, 1969.

Marschner, B., Brodowski, X., Dreves, A., Gleixner, G., Gude, A., Grootes, P. M., Hamer, U., Heim, A., Jandl, G., Ji, R., Kaiser, K., Kalbitz, K., Kramer, C., Leinweber, P., Rethemeyer, J., Schaffer, A., Schmidt, M. W. I., Schwark, L., and Wiesenberg, G. L. B.: How relevant is recalcitrance for the stabilization of organic matter in soils?, J. Plant Nutr. Soil Sc., 171, 91-132, 2008.

Maximovich, S. V.: Geography and ecology of cryogenic soils of Mongolia, in: Cryosols - Permafrost-Affected Soils, edited by: Kimble, J. M., Springer-Verlag, Berlin, 253-270, 2004.

McGuire, A. D., Anderson, L. G., Christensen, T. R., Dallimore, S., Guo, L., Hayes, D. J., Heimann, M., Lorenson, T. D., Macdonald, R. W., and Roulet, N.: Sensitivity of the carbon cycle in the Arctic to climate change, Ecol. Monogr., 79, 523-555, 2009.

Megonigal, J. P., Hines, M. E., and Visscher, P. T.: Anaerobic metabolism: Linkages to trace gases and aerobic processes, in: Vol. 8, Biogeochemistry, edited by: Schlesinger, W. H., Holland, H. D. and Turekian, K. K. (Editors-in-Chief), ElsevierPergamon, Oxford, UK, 317-424, 2004.

Melillo, J. M., Steudler, P. A., Aber, J. D., Newkirk, K., Lux, H., Bowles, F. P., Catricala, C., Magill, A., Ahrens, T., and Morrisseau, S.: Soil warming and carbon-cycle feedbacks to the climate system, Science, 298, 2173-2176, 2002.

Michaelson, G. J. and Ping, C. L.: Soil organic carbon and $\mathrm{CO}_{2}$ respiration at subzero temperature in soils of Arctic Alaska, J. Geophys. Res., 108, 8164, doi:10.1029/2001JD000920, 2003.

Michaelson, G. J., Ping, C. L., and Kimble, J. M.: Carbon storage and distribution in tundra soils of Arctic Alaska, USA, Arct. Alp. Res., 28, 414-424, doi:10.2307/1551852, 1996.

Michaelson, G. J., Ping, C. L., Kling, G. W., and Hobbie, J. E.: The character and bioavailability of dissolved organic matter at thaw and in spring runoff waters of the arctic tundra north slope, J. Geophys. Res., 103, 28939-28946, 1998.

Michaelson, G. J., Ping, C. L., Epstein, H. E., Kimble, J. M., and Walker, D. A.: Soils and frost boil ecosystems across the North American Arctic Transect, J. Geophys. Res., 113, G03S11, doi:10.1029/2007JG000672, 2008.

Michaelson, G. J., Ping, C. L., and Walker, D. A.: Soils associated with biotic activity on frost boils in Arctic Alaska, Soil Sci. Soc. Am. J., 76, 2265-2277, doi:10.2136/sssaj2012.0064, 2012.

Michaelson, G. J., Ping, C. L., and Clark, M. H.: Soil pedon carbon and nitrogen data for Alaska: An analysis and update, Open J. Soil Sci., 3, 132-142, doi:10.4236/ojss.2013.32015, 2013.
Mikan, C. J., Schimel, J. P., and Doyle, A. P.: Temperature controls of microbial respiration in arctic tundra soils above and below freezing, Soil Biol. Biochem., 34, 1785-1795, 2002.

Mishra, U. and Riley, W. J.: Alaskan soil carbon stocks: spatial variability and dependence on environmental factors, Biogeosciences, 9, 3637-3645, doi:10.5194/bg-9-3637-2012, 2012.

Mishra, U., Jastrow, J. D., Matamala, R., Hugelius, G., Koven, C. D., Harden, J. W., Ping, C. L., Michaelson, G. J., Fan, Z., Miller, R. M., McGuire, A. D., Tarnocai, C., Kuhry, P., Riley, W. J., Schaefer, K., Schuur, E. A. G., Jorgenson, M. T., and Hinzman, L. D.: Empirical estimates to reduce modeling uncertainties of soil organic carbon in permafrost regions: a review of recent progress and remaining challenges, Environ. Res. Lett., 8, 035020, doi:10.1088/1748-9326/8/3/035020, 2013.

Morgenstern, A., Ulrich, M., Günther, F., Roessler, S., Fedorova, I. V., Rudaya, N. A., Wetterich, S., Boike, J., and Schirrmeister, L.: Evolution of thermokarst in East Siberian ice-rich permafrost: A case study, Geomorphology, 201, 363-379, 2013.

Mueller, G., Broll, G., and Tarnocai, C.: Biological activity as influenced by microtopography in a cryosolic soil, Baffin Island, Canada, Permafrost Periglac., 10, 279-288, 1999.

Munn, L. C.: Soil genesis associated with periglacial ice wedge casts, southcentral Wyoming, Soil Sci. Soc. Am. J., 51, 10001004, 1987.

Munn, L. C. and Spackman, L. K.: Origin of silt-enriched alpine surface mantles in Indian Basin, Wyoming, Soil Sci. Soc. Am. J., 54, 1670-1677, 1990.

Murton, J. B. and French, H. M.: Cryostructures in permafrost, Tuktoyaktuk coastlands, western arctic Canada, Can. J. Earth Sci., 31, 737-747, 1994.

Oechel, W. C., Hastings, S. J., Vourlitis, G., Jenkins, M., Riechers, G., and Grulke, N.: Recent change of arctic tundra ecosystems from a net carbon dioxide sink to a source, Nature, 361, 520523, 1993.

Olefeldt, D., Turetsky, M. R., Crill, P. M., and McGuire, A D.: Environmental and physical controls on northern terrestrial methane emissions across permafrost zones, Glob. Change Biol., 19, 589-603, doi:10.1111/gcb.12071, 2013.

Ostroumov, V. E., Hoover, R., Ostroumova, N. V., Van Vliet-Lanoe, B., Siegert, C., and Sorokovikov, V.: Redistribution of soluble components during ice segregation in freezing ground, Cold Reg. Sci. Technol., 32, 175-182, 2001.

Outcalt, S. I., Nelson, F. E., and Hinkel, K. M.: The zero-curtain effect: Heat and mass transfer across an isothermal region in freezing soil, Water Resour. Res., 26, 1509-1516, 1990.

Paré, M. C. and Bedard-Haughn, A.: Soil organic matter quality influences mineralization and GHG emissions in cryosols: a fieldbased study of sub- to high Arctic, Glob. Change Biol., 19, 11261140, 2013.

Patrick, W. H. and Jugsujinda, A.: Sequential reduction and oxidation of inorganic nitrogen, manganese, and iron in flooded soil, Soil Sci. Soc. Am. J., 56, 1071-1073, 1992.

Pautler, B. G., Simpson, A. J., McNally, D. J., Lamoureux, S. F., and Simpson, M. J.: Arctic permafrost active layer detachments stimulate microbial activity and degradation of soil organic matter, Environ. Sci. Technol., 44, 4076-4082, 2010.

Pawluk, S.: Freeze-thaw effects on granular structure reorganization for soil materials of varying texture and moisture content, Can. J. Soil Sci., 68, 485-494, 1988. 
Pedersen, J. A., Simpson, M. A., Bockheim, J. G., and Kumar, K.: Characterization of soil organic carbon in drained thaw-lake basins of Arctic Alaska using NMR and FTIR photoacoustic spectroscopy, Org. Geochem., 42, 947-954, 2011.

Pengerud, A., Cécillon, L., Johnsen, L. K., Rasse, D. P., and Strand, L. T.: Permafrost distribution drives soil organic matter stability in a subarctic palsa peatland, Ecosystems, 16, 934-947, 2013.

Pettapiece, W. W.: A hummocky permafrost soil from the subarctic of northwestern Canada and some influences of fire, Can. J. Soil Sci., 54, 343-355, 1974.

Péwé, T.: Quaternary Geology of Alaska, US Geological Survey, US Govt. Printing Office, Washington, DC, Geological Survey Professional Paper 835, 1975.

Ping, C. L.: Gelisols: Part I. Cryogenesis and state factors of formation, Soil Horizons, 54(3), 1-5, doi:10.2136/sh2013-54-3-gc, 2013.

Ping, C. L., Lynn, W., and Smith, C. A. S.: Redoximorphic features in permafrost soils, in: Proceedings Joint Russian-American Seminar on Cryopedology and Global Change, Pushchino, Russia, 15-16 November 1992, edited by: Gilichinsky, D., Russian Academy of Sciences, Moscow, 233-244, 1993.

Ping, C. L., Michaelson, G. J., and Cherkinsky, A.: Characterization of soil organic matter by stable isotopes and radiocarbon ages of selected soils in Arctic Alaska, in: The Role of Humic Substances in the Ecosystem and in Environmental Protection, edited by: Drozd, J., Gonet, S. S., Senesi, N., and Weber, J., Polish Society of Humic Substances, Wroclaw, Poland, 475-480, 1997.

Ping, C. L., Bockheim, J. G., Kimble, J. M., Michaelson, G. J., and Walker, D. A.: Characteristics of cryogenic soils along a latitudinal transect in arctic Alaska, J. Geophys. Res., 103, 2891728928, doi:10.1029/98JD02024, 1998.

Ping, C. L., Clark, M. H., and Swanson, D. K.: Cryosols in Alaska, in: Cryosols - Permafrost-Affected Soils, edited by: Kimble, J., Springer-Verlag, Berlin, 71-94, 2004.

Ping, C. L., Michaelson, G. J., Packee, E. C., Stiles, C. A., Swanson, D. K., and Yoshikawa, K.: Soil catena sequences and fire ecology in the boreal forest of Alaska, Soil Sci. Soc. Am. J., 69, 17611772, 2005a.

Ping, C. L., Michaelson, G. J., Kimble, J. M., and Walker, D. A.: Soil acidity and exchange properties of cryogenic soils in Arctic Alaska, Soil Sci. Plant Nutr., 51, 649-653, 2005b.

Ping, C. L., Michaelson, G. J., Kimble, J. M., Romanovsky, V. E., Shur, Y. L., Swanson, D. K., and Walker, D. A.: Cryogenesis and soil formation along a bioclimate gradient in Arctic North America, J. Geophys. Res., 113, G03S12, doi:10.1029/2008JG000744, 2008a.

Ping, C. L., Michaelson, G. J., Jorgenson, M. T., Kimble, J. M., Epstein, H., Romanovsky, V. E., and Walker, D. A.: High stocks of soil organic carbon in the North American Arctic region, Nat. Geosci., 1, 615-619, doi:10.1038/ngeo284, 2008b.

Ping, C. L., Michaelson, G. J., Kane, E., Packee, E. C., Stiles, C. A., Swanson, D. K., and Zaman, N. D.: Carbon stores and biogeochemical properties of soils under black spruce forest, Alaska, Soil Sci. Soc. Am. J., 74, 969-978, 2010.

Ping, C. L., Michaelson, G. J., Guo, L., Jorgenson, M. T., Kanevskiy, M., Shur, Y., Dou, F., and Liang, J.: Soil carbon and material fluxes across the eroding Alaska Beau- fort Sea coastline, J. Geophy. Res.-Biogeo., 116, G02004, doi:10.1029/2010JG001588, 2011.

Ping, C. L., Clark, M. H., Kimble, J. M., Michaelson, G. J., Shur, Y., and Stiles, C. A.: Sampling protocols for permafrost-affected soils, Soil Horizons, 54(1), 13-19, doi:10.2136/sh12-09-0027, 2013.

Ping, C. L., Jastrow, J. D., Jorgenson, M. T., Matamala, R., Michaelson, G. J., and Shur, Y.: Soils and cryostratigraphy of ice wedge polygons in Arctic Alaska, Book of Abstracts of EUCOP4 4th European Conference on Permafrost, Evora, Portugal, 18-21 June 2014, 2014.

Pizano, C., Barón, A. F., Schuur, E. A. G., Crummer, K. G., and Mack, M. C.: Effects of thermo-erosional disturbance on surface soil carbon and nitrogen dynamics in upland arctic tundra, Environ. Res. Lett., 9, 075006, doi:10.1088/1748-9326/9/7/075006, 2014.

Post, W. M., Emanuel, W. R., Zinke, P. J., and Stangenberger, A. G.: Soil carbon pools and world life zones, Nature, 298, 156159, 1982.

Reyes, A. V., Froese, D. G., and Jensen, B. J. L.: Permafrost response to last interglacial warming: field evidence from nonglaciated Yukon and Alaska, Quaternary Sci. Rev., 29, 32563274, 2010.

Rieger, S.: The Genesis and Classification of Cold Soils, Academic Press, New York, 230 pp., 1983.

Rieger, S., Schoephorster, D. B., and Furbush, C. E.: Exploratory Soil Survey of Alaska, US Department of Agriculture, Soil Conservation Service, Washington, DC, 1979.

Rivkina, E., Shcherbakova, V., Laurinavichius, K., Petrovskaya, L., Krivushin, K., Kraev, G., Pecheritsina, S., and Gilichinsky, D.: Biogeochemistry of methane and methanogenic archaea in permafrost, FEMS Microbiol. Ecol. 61, 1-15, 2007.

Rodionov, A., Flessa, H., Grabe, M., Kazansky, O. A., Shibistova, O., and Guggenberger, G.: Organic carbon and total nitrogen variability in permafrost-affected soils in a forest tundra ecotone, Eur. J. Soil Sci., 58, 1260-1272, 2007.

Romanovsky, V. E. and Osterkamp, T. E.: Effects of unfrozen water in heat and mass transport processes in the active layers and permafrost, Permafrost Periglac., 11, 219-239, 2000.

Romanovsky, V. E., Marchenko, S. S., Daanen, R., Sergeev, D. O., and Walker, D. A.: Soil climate and frost heave along the Permafrost/Ecological North American Arctic Transect, in: Proceedings of the Ninth International Conference on Permafrost, Vol. 2, Fairbanks, Alaska, 28 June-3 July 2008, edited by: Kane, D. L. and Hinkel, K. M., Institute of Northern Engineering, University of Alaska Fairbanks, 1519-1524, 2008.

Romanovsky, V. E., Smith, S. L., and Christiansen, H. H.: Permafrost thermal state in the polar Northern Hemisphere during the international polar year 2007-2009: A synthesis, Permafrost Periglac., 21, 106-116, 2010.

Rowland, J. C., Jones, C. E., Altmann, G., Bryan, R., Crosby, B. T., Geernaert, G. L., Hinzman, L. D., Kane, D. L., Lawrence, D. M., Mancino, A., Marsh, P., McNamara, J. P., Romanovsky, V. E., Toniolo, H., Travis, B. J., Trochim, E., and Wilson, C. J.: Arctic landscapes in transition: Responses to thawing permafrost, Eos, 91, 229-230, 2010.

Rubey, W. W.: Geologic history of sea water: An attempt to state the problem, Geol. Soc. Am. Bull., 62, 1111-1148, 1951. 
Sannel, A. B. K. and Kuhry, P.: Holocene peat growth and decay dynamics in sub-arctic peat plateaus, west-central Canada, Boreas, 38, 13-24, 2009.

Sannel, A. B. K. and Kuhry, P.: Warming-induced destabilization of peat plateau/thermokarst lake complexes, J. Geophys. Res., 116, G03035, doi:10.1029/2010JG001635, 2011.

Schädel, C., Schuur, E. A. G., Bracho, R., Elberling, B., Knoblauch, C., Lee, H., Luo, Y., Shaver, G. R., and Turetsky, M. R.: Circumpolar assessment of permafrost $\mathrm{C}$ quality and its vulnerability over time using long-term incubation data, Glob. Change Biol., 20, 641-652, 2014.

Schaefer, K., Zhang, T., Bruhwiler, L., and Barrett, A. P.: Amount and timing of permafrost carbon release in response to climate warming, Tellus B, 63, 165-180, 2011.

Schirrmeister, L., Siegert, C., Kunitzky, V. V., Grootes, P. M., and Erlenkeuser, H.: Late Quaternary ice-rich permafrost sequences as a paleoenvironmental archive for the Laptev Sea Region in northern Siberia, Int. J. Earth Sci., 91, 154-167, 2002a.

Schirrmeister, L., Siegert, C., Kuznetsova, T., Kuzmina, S., Andreev, A., Kienast, F., Meyer, H., and Bobrov, A.: Paleoenvironmental and paleoclimatic records from permafrost deposits in the Arctic region of Northern Siberia, Quaternary Int., 89, 97-118, 2002b.

Schirrmeister, L., Kunitsky, V. V., Grosse, G., Kuznetsova, T. V., Derevyagin, A. Y., Wetterich, S., and Siegert, C.: The Yedoma Suite of the Northeastern Siberian Shelf Region characteristics and concept of formation, in: Proceedings, Ninth International Conference on Permafrost, Fairbanks, Alaska, 28 June-3 July 2008, edited by: Kane, D. L. and Hinkel, K. M., Institute of Northern Engineering, University of Alaska Fairbanks, 287-288, 2008.

Schirrmeister, L., Grosse, G., Wetterich, S., Overduin, P. P., Strauss, J., Schuur, E. A. G., and Hubberten, H.-W.: Fossil organic matter characteristics in permafrost deposits of the northeast Siberian Arctic, J. Geophys. Res., 116, G00M02, doi:10.1029/2011JG001647, 2011a.

Schirrmeister, L., Kunitsky, V., Grosse, G., Wetterich, S., Meyer, H., Schwamborn, G., Babiy, O., Derevyagin, A., and Siegert, C.: Sedimentary characteristics and origin of the Late Pleistocene Ice Complex on north-east Siberian Arctic coastal lowlands and islands - a review, Quaternary Int., 241, 3-25, 2011 b.

Schirrmeister, L., Froese, D., Tumskoy, V., Grosse, G., and Wetterich, S.: Yedoma: Late Pleistocene ice-rich syngenetic permafrost of Beringia, in: The Encyclopedia of Quaternary Science, Vol. 3, edited by: Elias, S. A., Elsevier, Amsterdam, 542552,2013

Schlesinger, W. H.: Carbon balance in terrestrial detritus, Annu. Rev. Ecol. Syst., 8, 51-81, 1977.

Schneider von Deimling, T., Meinshausen, M., Levermann, A., Huber, V., Frieler, K., Lawrence, D. M., and Brovkin, V.: Estimating the near-surface permafrost-carbon feedback on global warming, Biogeosciences, 9, 649-665, doi:10.5194/bg-9-649-2012, 2012.

Schuur, E. A. G., Bockheim, J., Canadell, J. G., Euskirchen, E., Field, C. B., Goryachkin, S. V., Hagemann, S., Kuhry, P., Lafleur, P. M., Lee, H., Mazhitova, G., Nelson, F. E., Rinke, A., Romanovsky, V. E., Shiklomanov, N., Tarnocai, C., Venevsky, S., Vogel, J. G., and Zimov, S. A.: Vulnerability of permafrost carbon to climate change: Implications for the global carbon cycle, BioScience, 58, 701-714, 2008.
Schuur, E. A. G., Vogel, J. G., Crummer, K. G., Lee, H., Sickman, J. O., and Osterkamp, T. E.: The effect of permafrost thaw on old carbon release and net carbon exchange from tundra, Nature, 459, 556-559, doi:10.1038/nature08031, 2009.

Schuur, E. A. G., Abbott, B. W., Bowden, W. B., Brovkin, V., Camill, P., Canadell, J. P., Chapin III, F. S., Christensen, T. R., Chanton, J. P., Ciais, P., Crill, P. M., Crosby, B. T., Czimczik, C. I., Grosse, G., Hayes, D. J., Hugelius, G., Jastrow, J. D., Kleinen, T., Koven, C. D., Krinner, G., Kuhry, P., Lawrence, D. M., Natali, S. M., Ping, C. L., Rinke, A., Riley, W. J., Romanovsky, V. E., Sannel, A. B. K., Schädel, C., Schaefer, K., Subin, Z. M., Tarnocai, C., Turetsky, M., Walter Anthony, K. M., Wilson, C. J., and Zimov, S. A.: High risk of permafrost thaw, Nature, 480, 32-33, doi:10.1038/480032a, 2011.

Schwertmann, U. and Taylor, R. M.: Iron oxides, in: Minerals in Soil Environments (2nd Edn.), edited by: Dixon, J. B. and Weed, S. B., SSSA Book Series No.1, Soil Science Society of America, Madison, WI, 379-438, 1989.

Shilts, W. W.: Nature and genesis of mudboils, central Keewatin, Canada, Can. J. Earth Sci., 15, 1053-1068, 1978.

Shishov, L. L., Tonkonogov, V. D., Lebedeva, I. I., and Gerasimova, M. I.: Classification and diagnostics of soils of Russia, Oikumena, Smolensk, Russia, 2004.

Shur, Y. L.: The upper horizon of permafrost soils, in: Proceedings of the Fifth International Conference on Permafrost, Vol. 1, edited by: Senneset, K., Tapir Publishers, Trondheim, Norway, 867-871, 1988.

Shur, Y. L. and Jorgenson, M. T.: Cryostructure development on the floodplain of the Colville River Delta, northern Alaska, in: Proceedings of Seventh International Conference on Permafrost, Yellowknife, Canada, edited by: Lewkowicz, A. G. and Allard, M., Universite Laval, Centre d'études nordiques, Collection Nordicana, 57, 993-999, 1998.

Shur, Y. L. and Jorgenson, M. T.: Patterns of permafrost formation and degradation in relation to climate and ecosystems, Permafrost Periglac., 18, 7-19, 2007.

Shur, Y. and Osterkmap, T. E.: Thermokarst, Institute of Northern Engineering, University of Alaska Fairbanks, Fairbanks, AK, Rep. INE 06.11, 50 pp., 2007.

Shur, Y. L. and Ping, C. L.: Permafrost dynamics and soil formation, in: Proceedings of the Meetings on the Classification, Correlation, and Management of Permafrost-affected Soils, edited by: Kimble, J. M. and Ahrens, R. J., USDA Soil Conserv. Serv.-Nat. Soil Surv. Cent., Lincoln, NE, 112-117, 1994.

Shur, Y. and Zhestkova, T.: Cryogenic structure of a glaciolacustrine deposit, in: Proceedings of the Eighth International Conference on Permafrost, edited by: Phillips, M., Springman, S. M., and Arenson, L. U., Zurich, Switzerland, vol. 2, 1051-1056, 2003.

Shur, Y., Hinkel, K. M., and Nelson, F. E.: The transient layer: Implications for geocryology and climate-change science, Permafrost Periglac., 16, 5-17, 2005.

Shur, Y., Jorgenson, T., Kanesvskiy, M., and Ping, C. L.: Formation of frost boils and earth hummocks, in: Ninth International Conference on Permafrost, Fairbanks, Alaska, 28 June-3 July 2008, Extended Abstracts, edited by: Kane, D. L. and Hinkel, K. M., Institute of Northern Engineering, University of Alaska Fairbanks, 287-288, 2008. 
Simas, F. N. B., Schaefer, C. E. G. R., Mendonca, E. S., Silva, I. R., Santana, R. M., and Ribeiro, A. S. S.: Organic carbon stocks in permafrost-affected soils from Admiralty Bay, Antarctica, U.S. Geological Survey and The National Academies, USGS OF-2007-1047, Short Research Paper 076, doi:10:3133/of20071047.srp076, 2007.

Simpson, M. J. and Simpson, A. J.: The chemical ecology of soil organic matter molecular constituents, J. Chem. Ecol., 38, 768784, 2012.

Smith, C. A. S., Fox, C. A., and Hargrave, A. E.: Development of soil structure in some turbic cryosols in the Canadian low arctic, Can. J. Soil Sci., 71, 11-29, 1991.

Smith, C. A. S, Swanson, D. K., Moore, J. P., Ahrens, R. J., Bockheim, J. G., Kimble, J. M., Mazhitova, G. G., Ping, C. L., and Tarnocai, C.: A description and classification of soils and landscapes of the Lower Kolyma River, Northern Russia, Polar Geogr. Geol., 19, 107-126, doi:10.1080/10889379509377563, 1995.

Soil Classification Working Group: The Canadian System of Soil Classification. Agriculture and Agri-Food Canada Publication 1646, NRC Research Press, National Research Council of Canada, Ottawa, Canada, 1998.

Soil Survey Staff: Soil Taxonomy: A Basic System of Soil Classification for Making and Interpreting Soil Surveys, 1st Edn., Agric. Handb. 436, USDA-SCS, US Gov. Print. Office, Washington, DC, 1975.

Soil Survey Staff: Soil Taxonomy: A Basic System of Soil Classification for Making and Interpreting Soil Surveys, 2nd Edn., Agric. Handb. 436, USDA-NRCS, US Gov. Print. Office, Washington, DC, 1999.

Soil Survey Staff: Kellogg Soil Survey Laboratory Methods Manual, Soil Survey Investigations Report No. 42, Ver. 5, edited by: Burt, R., U.S. Department of Agriculture, Natural Resources Conservation Service, p. 712, 2014.

Stolbovoi, V.: Carbon in Russian soils, Clim. Change, 55, 131-156, 2002.

Strauss, J., Schirrmeister, L., Wetterich, S., Borchers, A., and Davydov, S. P.: Grain-size properties and organic-carbon stock of Yedoma Ice Complex permafrost from the Kolyma lowland, northeastern Siberia, Global Biogeochem. Cy., 26, GB3003, doi:10.1029/2011GB004104, 2012.

Strauss, J., Schirrmeister, L., Grosse, G., Wetterich, S., Ulrich, M., Herzschuh, U., and Hubberten, H.-W.: The deep permafrost carbon pool of the Yedoma Region in Siberia and Alaska, Geophys. Res. Lett., 40, 6165-6170, doi:10.1002/2013g1058088, 2013.

Sumgin, M.: Permafrost in the USSR, Far-East Geophysical Observatory, Vladivostok, Nauka, Moscow, 370 pp., 1927 (in Russian).

Sutton, R. and Sposito, G.: Molecular structure in soil humic substances: The new view, Environ. Sci. Technol., 39, 9009-9015, 2005.

Swanson, D. K., Ping, C. L., and Michaelson, G. J.: Diapirism in soils due to thaw of ice-rich materials near the permafrost table, Permafrost Periglac., 10, 349-367, 1999.

Tarnocai, C.: The amount of organic carbon in various soil orders and ecological provinces in Canada, in: Soil Processes and the Carbon Cycle, edited by: Lal, R., Kimble, J. M., Follett, R. F., and Stewart, B. A., CRC Press, Boca Raton, Florida, 81-92, 1998.

Tarnocai, C. and Lacelle, B.: Soil Organic Carbon of Canada Map, Eastern Cereal and Oilseed Research Centre, Agriculture and
Agri-Food Canada, Research Branch, Ottawa, Ontario, Canada, 1996.

Tarnocai, C. and Smith, C. A. S.: The formation and properties of soils in the permafrost regions of Canada, in: Cryosols: The Effects of Cryogenesis on the Processes and Peculiarities of Soil Formation, Proceedings of the 1st International Conference on Cryopedology, Pushchino, Russia, 10-16 November 1992, edited by: Gilichinsky, D. A., Russian Academic of Science, Pushchino, Russia, 21-42, 1992.

Tarnocai, C. and Zoltai, S. C.: Earth hummocks of the Canadian Arctic and Subarctic, Arctic Alpine Res., 11, 581-594, 1978.

Tarnocai, C., Walker, D. A., and Broll, G.: Turf hummocks in Arctic Canada: Characteristics and development, Eos Trans. AGU, 87, Fall Meet. Suppl., Abstract C51A-0381, 2006.

Tarnocai, C., Canadell, J. G., Schuur, E. A. G., Kuhry, P., Mazhitova, G., and Zimov, S. A.: Soil organic carbon pools in the northern circumpolar permafrost region, Global Biogeochem. Cy., 23, GB2023, doi:10.1029/2008GB003327, 2009.

Tedrow, J. C. F.: Soil of the Polar Regions, Rutgers Univ. Press, New Brunswick, N. J., 1974.

Treat, C. C., Wollheim, W. M., Varner, R. K., Grandy, A. S., Talbot, J., and Frolking, S.: Temperature and peat type control $\mathrm{CO}_{2}$ and $\mathrm{CH}_{4}$ production in Alaskan permafrost peats, Glob. Change Biol., 20, 2674-2686, 2014.

Tsytovich, N. A.: The Mechanics of Frozen Ground, Scripta/McGraw-Hill, New York, 426 pp., 1975.

Turetsky, M. R., Wieder, R. K., Vitt, D. H., Evans, R. J., and Scott, K. D.: The disappearance of relict permafrost in boreal north America: Effects on peatland carbon storage and fluxes, Glob. Change Biol., 13, 1922-1934, 2007.

Uhlîrová, E., Šantrůčková, H., and Davidov, S. P.: Quality and potential biodegradability of soil organic matter preserved in permafrost of Siberian tussock tundra, Soil Biol. Biochem., 39, 1978-1989, 2007.

van Cleve, K., Dyrness, C. T., Viereck, L., Fox, J., Chapin III, F. S., and Oechel, W.: Taiga ecosystems in interior Alaska, Bioscience, 33, 39-44, 1983.

Vandenberghe, J.: Cryoturbations, in: Advances in Periglacial Geomorphology, edited by: Clark, M. J., John Wiley \& Sons Ltd., 1988.

van Everdingen, R. O.: Frost mounds at Bear Rock, near Fort Norman, Northwest Territories, 1975-1976, Can. J. Earth Sci., 15, 263-276, 1978.

Veremeeva, A. and Gubin, S.: Modern tundra landscapes of the Kolyma Lowland and their evolution in the Holocene, Permafrost Periglac., 20, 399-406, 2009.

Vonk, J. E., Sánchez-García, L., van Dongen, B. E., Alling, V., Kosmach, D., Charkin, A., Semiletov, I. P., Dudarev, O. V., Shakhova, N., Roos, P., Eglinton, T. I., Andersson, A., and Gustafsson, Ö.: Activation of old carbon by erosion of coastal and subsea permafrost in Arctic Siberia, Nature, 489, 137-140, 2012.

von Lützow, M., Kögel-Knabner, I., Ekschmitt, K., Matzner, E., Guggenberger, G., Marschner, B., and Flessa, H.: Stabilization of organic matter in temperate soils: Mechanisms and their relevance under different soil conditions - A review, Eur. J. Soil Sci., 57, 426-445, 2006.

von Lützow, M., Kögel-Knabner, I., Ekschmitt, K., Flessa, H., Guggenberger, G., Matzner, E., and Marschner, B.: SOM frac- 
tionation methods: relevance to functional pools and to stabilization mechanisms, Soil Biol. Biochem., 39, 2183-2207, 2007.

Wagner, D., Gattinger, A., Embacher, A., Pfeiffer, E.-M., Schloter, M., and Lipski, A.: Methanogenic activity and biomass in Holocene permafrost deposits of the Lena Delta, Siberian Arctic and its implication for the global methane budget, Glob. Change Biol., 13, 1089-1099, 2007.

Waldrop, M. P., Wickland, K. P., White III, R., Berhe, A. A., Harden, J. W., and Romanovsky, V. E.: Molecular investigations into a globally important carbon pool: Permafrost-protected carbon in Alaskan soils, Glob. Change Biol., 16, 2543-2554, 2010.

Walker, D. A., Epstein, H. E., Gould, W. A., Kelley, A. M., Kade, A. N., Knudson, J. A., Krantz, W. B., Michaelson, G. J., Peterson, R. A., Ping, C. L., Raynolds, M. K., Romanovsky, V. E., and Shur, Y.: Frost-boil ecosystems: complex interactions between landforms, soils, vegetation, and climate, Permafrost Periglac., 15, 171-188, 2004.

Walker, D. A., Epstein, H. E., Romanovsky, V. E., Ping, C. L., Michaelson, G. J., Daanen, R. P., Shur, Y., Peterson, R. A., Krantz, W. B., Raynolds, M. K., Gould, W. A., Gonzalez, G., Nickolsky, D. J., Vonlanthen, C. M., Kade, A. N., Kuss, P., Kelley, A. M., Munger, C. A., Tarnocai, C., Matveyeva, N. V., and Daniëls, F. J. A.: Arctic patterned-ground ecosystems: a synthesis of field studies and models along a North American Arctic Transect, J. Geophys. Res., 113, G03S01, doi:10.1029/2007JG000504, 2008.

Walmsley, M. E. and Lavkulich, L. M.: Chemical, physical, and land-use investigations of organic terrain, Can. J. Soil Sci., 55, 331-342, 1975

Walter, K. M., Edwards, M. E., Grosse, G., Zimov, S. A., Chapin III, F. S.: Thermokarst lakes as a source of atmospheric $\mathrm{CH}_{4}$ during the last deglaciation, Science, 318, 633-636, 2007.

Walter Anthony, K. M., Zimov, S. A., Grosse, G., Jones, M. C., Anthony, P. M., Chapin III, F. S., Finlay, J. C., Mack, M. C., Davydov, S., Frenzel, P., and Frolking, S.: A shift of thermokarst lakes from carbon sources to sinks during the Holocene epoch, Nature, 511, 452-456, doi:10.1038/nature13560, 2014.

Washburn, A. L.: Periglacial Processes and Environment, St. Martin's Press, New York, 1973.

Washburn, A. L.: Geocryology: a Survey of Periglacial Processes and Environments, Wiley, New York, 406 pp., 1980.

Weintraub, M. N. and Schimel, J. P.: Interactions between carbon and nitrogen mineralization and soil organic matter chemistry in Arctic tundra soils, Ecosystems, 6, 129-143, 2003.

White, D. M., Garland, D. S., Dai, X.-Y., and Ping, C. L.: Fingerprinting soil organic matter in the Arctic to help predict $\mathrm{CO}_{2}$ flux, J. Cold Reg. Sci. Technol., 35, 185-194, 2002.

White, D. M., Garland, D. S., Ping, C. L., and Michaelson, G. J.: Characterizing soil organic matter quality in arctic soil by cover type and depth, J. Cold Reg. Sci. Technol., 38, 63-73, 2004.

Wild, B., Schnecker, J., Eloy Alves, R. J., Barsukov, P., Bárta, J., Čapek, P., Gentsch, N., Gittel, A., Guggenberger, G., Lashchinskiy, N., Mikutta, R., Rusalimova, O., Šantrůčková, H., Shibistova, O., Urich, T., Watzka, M., Zrazhevskaya, G., and Richter, A.: Input of easily available organic $\mathrm{C}$ and $\mathrm{N}$ stimulates microbial decomposition of soil organic matter in arctic permafrost soil, Soil Biol. Biochem., 75, 143-151, 2014.
Williams, P. J. and Smith, M. W.: The Frozen Earth: Fundamentals of Geocryology, Cambridge University Press, Cambridge, UK, 1989.

Winterfeld, M., Schirrmeister, L., Grigoriev, M. N., Kunitsky, V. V., Andreev, A., Murray, A., and Overduin, P. P.: Coastal permafrost landscape development since the Late Pleistocene in the western Laptev Sea, Siberia, Boreas, 40, 697-713, doi:10.1111/j.15023885.2011.00203.x, 2011.

Xu, C. H., Dou, F., Guo, L., and Ping, C. L.: Potential DOC production from size fractionated arctic tundra soils, Cold Reg. Sci. Technol., 55, 114-150, 2009a.

$\mathrm{Xu}, \mathrm{C}$, Guo, L., Ping, C. L., and White, D. M.: Chemical and isotopic characterization of size fractionated organic matter from cryoturbated tundra soils, northern Alaska, J. Geophy. Res.Biogeo., 114, G03002, doi:10.1029/2008JG000846, 2009b.

Zhang, T., Barry, R. G., Knowles, K., Heginbottom J. A., and Brown J.: Statistics and characteristics of permafrost and ground-ice distribution in the Northern Hemisphere. Polar Geography, 31, 4768, doi:10.1080/10889370802175895, 2008.

Zhestkova, T. N.: Formation of Soil Cryogenic Structure. Nauka, Moscow, 216 pp., 1982 (in Russian).

Zhuang, Q., Melillo, J. M., Sarofim, M. C., Kicklighter, D. W., McGuire, A. D., Felzer, B. S., Sokolov, A., Prinn, R. G., Steudler, P. A., and $\mathrm{Hu}, \mathrm{S} .: \mathrm{CO}_{2}$ and $\mathrm{CH}_{4}$ exchanges between land ecosystems and the atmosphere in northern high latitudes over the 21st century, Geophy. Res. Lett., 33, L17403, doi:10.1029/2006GL026972, 2006.

Zhuang, Q., Melillo, J. M., McGuire, A. D., Kicklighter, D. W., Prinn, R. G., Steudler, P. A., Felzer, B. S., and Hu, S.: Net emissions of $\mathrm{CH}_{4}$ and $\mathrm{CO}_{2}$ in Alaska: Implications for the region's greenhouse gas budget, Ecolog. Appl., 17, 203-212, 2007.

Zimov, S. A., Zimova, G. M., Daviodov, S. P., Daviodova, A. I., Voropaev, Y. V., Voropaeva, Z. V., Prosiannikov, S. F., Prosiannikova, O. V., Semiletova, I. V., and Semiletov, I. P.: Winter biotic activity and production of $\mathrm{CO}_{2}$ in Siberian soils: a factor in the greenhouse effect, J. Geophy. Res.-Atmos., 98, 5017-5023, doi:10.1029/92JD02473, 1993.

Zimov, S. A., Davidov, S. P., Voropaev, Y. V., Prosiannikov, S. F., Semiletov, I. P., Chapin, M. C., and Chapin, F. S.: Siberian $\mathrm{CO}_{2}$ efflux in winter as a $\mathrm{CO}_{2}$ source and cause of seasonality in atmospheric $\mathrm{CO}_{2}$, Climatic Change, 33, 111-120, 1996.

Zimov, S. A., Schuur, E. A. G., and Chapin, F. S.: Permafrost and the global carbon budget, Science, 312, 1612-1613, doi:10.1126/science.1128908, 2006.

Zoltai, S. C. and Tarnocai, C.: Perennially frozen peatlands in the Western Arctic and Subarctic of Canada, Can. J. Earth Sci., 12, 28-43, 1975.

Zubrzycki, S., Kutzbach, L., Grosse, G., Desyatkin, A., and Pfeiffer, E.-M.: Organic carbon and total nitrogen stocks in soils of the Lena River Delta, Biogeosciences, 10, 3507-3524, doi:10.5194/bg-10-3507-2013, 2013.

Zubrzycki, S., Kutzbach, L., and Pfeiffer, E.-M.: Permafrostaffected soils and their carbon pools with a focus on the Russian Arctic, Solid Earth, 5, 595-609, doi:10.5194/se-5-595-2014, 2014. 